\title{
Low-Level Tank Waste Simulant Data
} Base

R. O. Lokken

April 1996

Prepared for

the U.S. Department of Energy

under Contract DE-AC06-76RLO 1830

Pacific Northwest National Laboratory

Richland, Washington 99352

DISTABUTION OF THIS DOCUMENT IS UNLIMITED 
PNNL-11116

UC-512

Project Technical Information

\section{Low-Level Tank Waste Simulant Data Base}

RO Lokken

April 1996

Prepared for

the U.S. Department of Energy

under Contract DE-AC06-76RLO 1830

Pacific Northwest National Laboratory

Richland, Washington 99352 


\title{
DISCLAIMER
}

This report was prepared as an account of work sponsored by an agency of the United States Government. Neither the United States Government nor any agency thereof, nor Battelle Memorial Institute, nor any of their employees, makes any warranty, express or implied, or assumes any legal liability or responsibility for the accuracy, completeness, or.usefulness of any information, apparatus, product, or process disclosed, or represents that its use would not infringe privately owned rights. Reference herein to any specific commercial product, process, or sevice by trade name, trademark, manufacturer, or othenvise does not necessarily constitute or imply its endorsement, recommendation, or favoring by the United States Government or any agency thereof, or Battelle Memorial Institute. The views and opinions of authors expressed herein do not necessarily state or reflect those of the United States Covernment or any agency thereof.

\author{
PACIFIC NORTHWEST NATIONAL LABORATORY \\ operated by \\ BATTELLE \\ for the \\ UNITED STATES DEPARTMENT OF ENERGY \\ under Contract DE-AC06-76RLO 1830
}

Printed in the United States of America

Available to DOE and DOE contractors from the

Office of Scientific and Technical information, P.O. Box 62, Oak Ridge, TN 37831; prices available from (615) 576-8401.

Available to the public from the National Technical Information Service, U.S. Department of Commerce, 5285 Port Royal Rd., Springfield, VA 22161 
SUMMARY

The majority of defense wastes generated from reprocessing spent $\mathrm{N}$-reactor fuel at Hanford are stored in underground Double-Shell Tanks (DST) and in older Single-Shell Tanks (SST). The Tank Waste Remediation System (TWRS) Program has the responsibility of safely managing and immobilizing these tank wastes for disposal. A reference process flowsheet is being developed that includes waste retrieval, pretreatment, and vitrification. Prior to the decision to vitrify the low-level wastes ( $L L W$ ), the disposal choice for Hanford DST LLW was to solidify the liquid wastes using cementitious grouts. Several DSTs were sampled and characterized and waste simulants were prepared for testing the grouting process. Most of the testing was done with simulants because of the large quantities required and the hazards associated with using actual radioactive tank wastes. Although several simulants were prepared and tested for use in the grout disposal tests, their use in LLW vitrification testing is limited because characterization data was limited to chemical analyses and density measurements and because their compositions did not reflect any changes that would occur as result of ion exchange, blending, and evaporation. However, observations from some of the grout simulant studies indicated that precipitation of aluminum hydroxide could occur when the $\mathrm{Al} / \mathrm{OH}$ ratio approached or exceeded one and that sodium phosphate may crystallize at ambient temperatures and/or when the phosphate levels were above about 0.2 molar.

For the first phase of LLW vitrification simulant development, two waste compositions were investigated. The simulated wastes were based on the analyses of six tanks of DSSF waste and on the projected composition of the wastes exiting the pretreatment operations. A simulant normalized to $6 \underline{M}$ sodium was based on the anticipated concentration after ion exchange and initial separations. A $10 \underline{M}$ sodium simulant would represent a waste that had been concentrated by evaporation to reduce the overall volume. A third LLW simulant, referred to as the remaining inventory, included wastes not included in the DSSF tanks and the projected LLW fraction of single-shell tank wastes. Additional simulant compositions will be developed and tested as retrieval sequences, blending strategies, and pretreatment flowsheets become finalized. 
Laboratory prepared simulants were characterized for settled solids. density, viscosity, moisture content, and chemical analyses. Following laboratory development and characterization of the simulants, a procedure was recommended for use in preparing large quantities of LLW simulant for use in the melter vendor tests. About 42,000 liters of simulant were prepared for use in melter vendor testing and about 940 liters were prepared for use in small-scale testing at PNL. Chemical analyses of these simulants are reported and compared with the target composition. 


\section{CONTENTS}

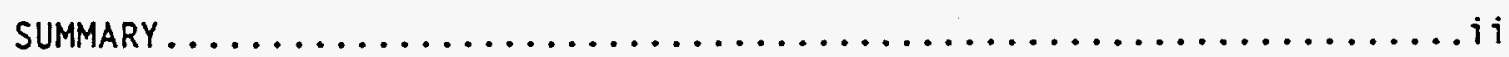

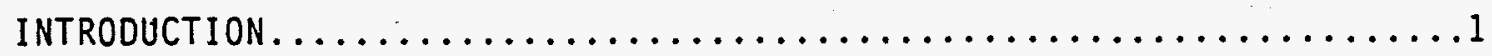

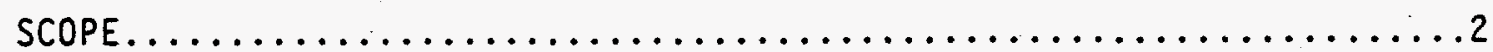

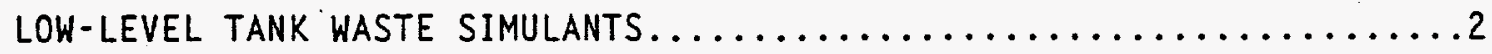

GROUT. DISPOSAL PROGRAM SIMULANTS $\ldots \ldots \ldots \ldots \ldots \ldots \ldots \ldots \ldots$

LLW VITRIFICATION SIMULANTS $\ldots \ldots \ldots \ldots \ldots \ldots \ldots \ldots \ldots \ldots \ldots \ldots \ldots$

LABORATORY DEVELOPMENT OF LLW VITRIFICATION SIMULANT...........

RECOMMENDED PROCEDURE FOR LLW SIMULANT PREPARATION............. 13

SIMULANT PREPARATION FOR MELTER VENDOR TESTS $\ldots \ldots \ldots \ldots \ldots \ldots \ldots \ldots 14$

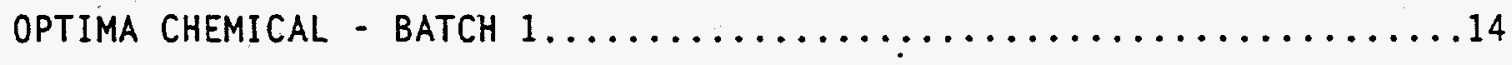

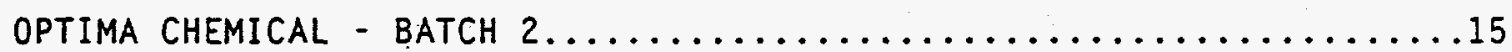

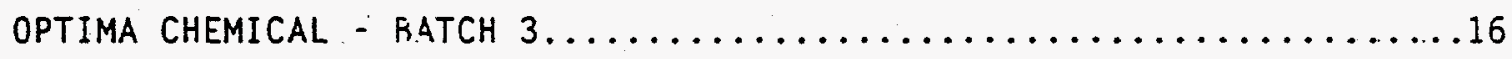

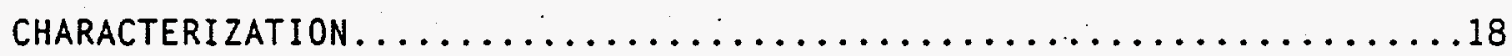

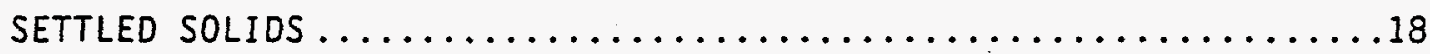

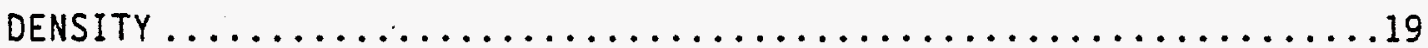

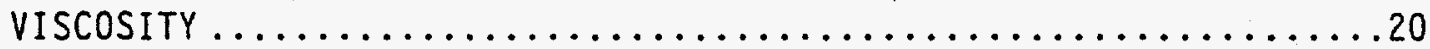

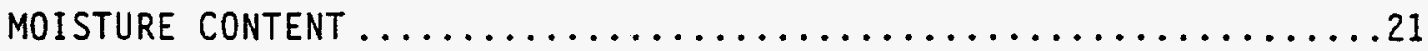

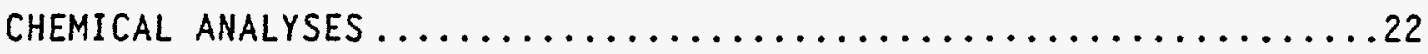

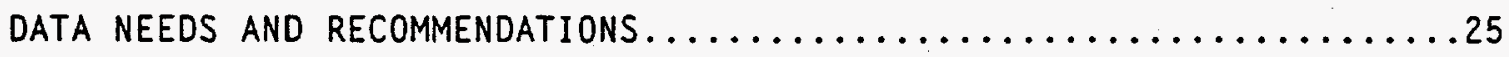

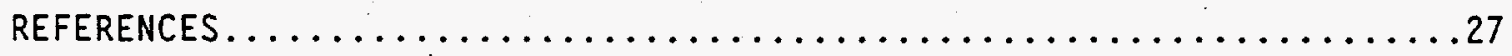

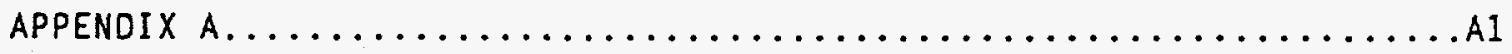

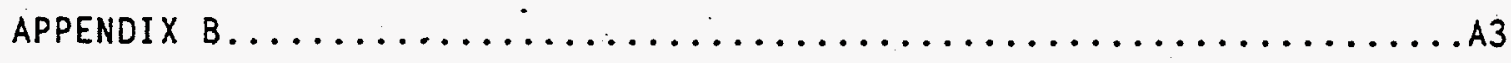

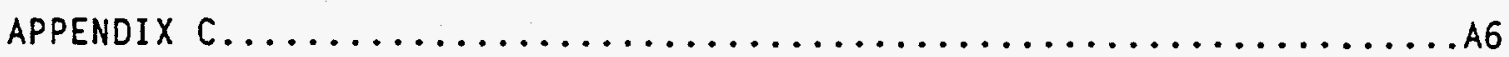




\section{TABLES}

1 Reported Concentrations of Select Major Species in Double-

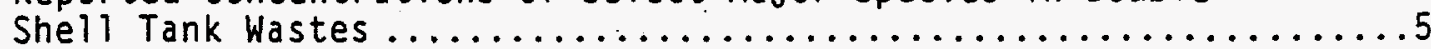

2 Target Compositions of Double-Shell Tank Simulants Used for

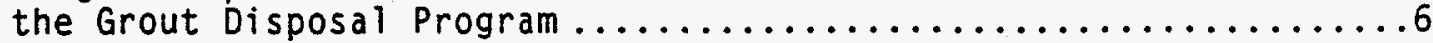

3 Target Concentrations of Low-Level Waste Simulants for

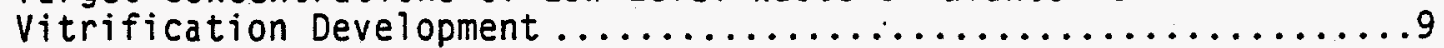

4 Recipe for DSSF Vitrification Simulant Normalized to $6 \mathrm{M} \mathrm{Na} \mathrm{.....10}$

5 Recipe for DSSF Vitrification Simulant Normalized to $10 \mathrm{M} \mathrm{Na} \ldots \ldots 11$

6 Recipe for Remaining Inventory Vitrification Simulant

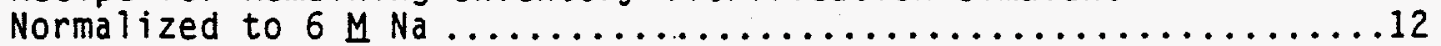

7 Batch Sheet for Preparation of $10 \mathrm{M} \mathrm{Na}$ LLW Simulant at Optima Chemical for Melter Vendor Tests and at PNL for a Pilot-Scale

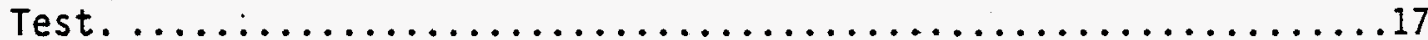

8 Estimated Volume Percent Settled Solids After 24 Hours for LLW Vitrification Simulants ................................. 19

9 Densities of Simulated or Actual Wastes $\ldots \ldots \ldots \ldots \ldots \ldots \ldots \ldots . \ldots 20$

10 Viscosity of Laboratory-Prepared LLW Simulants ..............21

11 Moisture Content of Simulated or Actual Tank Waste Samples .....21

12 Analyzed Chemical Composition of Laboratory-Produced

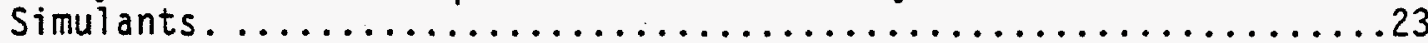

13 Chemical Analysis of LLW Simulant Prepared By Optima

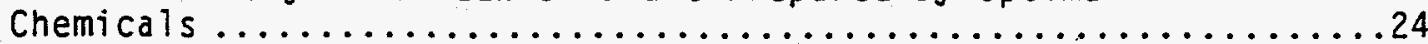




\section{ACRONYMS}

CC

CVS

DSSF

DST

GDP

ICP

LLW

NCRW

PNL

PSW

RI

SST

TWRS

WHC
Complexant Concentrate

Composition Variation Study

Double-Shell Slurry Feed

Double-Shell Tank

Grout Disposal Program

Inductively Coupled Plasma spectroscopy

Low-Level Waste

Neutralized Cladding Removal Waste

Pacific Northwest Laboratory

Phosphate-Sulfate Waste

Remaining Inventory

Single-Shell Tank

Tank-Waste Remediation System

Westinghouse Hanford Company 


\section{INTRODUCTION}

The majority of defense wastes generated from reprocessing spent $\mathbb{N}$-reactor fuel at Hanford are stored in underground Double-Shell Tanks (DST) and in older single-Shell Tanks (SST) in the form of liquids, slurries. sludges. and salt cakes. The Tank Waste Remediation System (TWRS) Program has the responsibility of safely manaing and immobilizing these tank wastes for disposal. A reference process flowsheet is being developed that includes waste retrieval, pretreatment, and vitrification.

Prior to the decision to vitrify the low-level wastes (LLW), the disposal choice for Hanford DST LLW was to solidify the liquid wastes using cementitious grouts. Westinghouse Hanford Company (WHC) managed the Grout Disposal Program (GDP) and Pacific Northwest Laboratory (PNL) provided support through tank waste characterization, simulant development, waste form development and testing, radioactive grout testing, pilot-scale tests, and performance assessments. Several types of liquid LLW were investigated for their potential disposal via grouting. These included Phosphate/Sulfate Waste (PSW). Neutralized Cladding Removal Waste (NCRW), Complexant Concentrate (CC), Double Shell Slurry Feed (DSSF), and Concentrated Phosphate Waste, i.e., from Tank 241-AN-106 (106-AN). Limited studies were performed with NCRW (Serne et al 1992) and with CC (Shade et al 1986). Extensive laboratory and pilot-scale studies have been conducted with PSW (Lokken et al 1987. Fow et al 1987. Serne et al 1992). DSSF (Claghorn 1987. Lokken 1992b, C Lokken and Martin 1992. Serne et al 1992, Whyatt 1994), and 106-AN (Bagasen 1993. Hammitt and Welsh 1993. Lokken 1992a, Lokken et al 1993, Serne et al 1992. Serne et al 1989. Welsh 1994a). Several simulants of these waste types were prepared and the compositions and densities of selected DSSF and 241-AN-106 simulants and actual DST waste are reported.

Currently. PNL is assisting in the development of waste forms for vitrifying Hanford LLW and supporting the Westinghouse Hanford Company melter technology selection. An integral part of the process is to identify. prepare. and characterize representative LLW simulants for use in these studies. During FY-94, procedures were developed for preparing waste simulants for use in laboratory vitrification studies and for Phase I vendor 
melter tests described in the PNL Project Work Plan and the WHC Vendor Test Statement of Work (Wilson 1994), respectively.

\section{SCOPE}

This report discusses three principal topics: the need for and the basis for selecting target or reference LLW simulants, tank waste analyses and simulants that have been defined, developed, and used for the GDP. and activities in support of preparing and characterizing simulants. for the current LLW vitrification project. The procedures and the data that were generated to characterize the $L L W$ vitrification simulants were reported by Lokken and Martin (1994) and for the most part, are presented in this report. Analyses of simulants prepared at Optima Chemicals for use by the melter vendors for Phase. I testing, and for a simulant prepared a.t PNL for use in small-scale melter testing in direct support of the melter vendor tests are presented. The final section of this report addresses the applicability of the data to the current program and presents recommendations for additional data needs including characterization and simulant compositional variability studies.

\section{LOW-LEVEL TANK WASTE SIMULANTS}

One of the most important activities in waste form development and testing is the development of a suitable simulant that matches as closely as possible the characteristics of the actual waste stream that will be processed. Ideally. preparation of a waste simulant would follow the same chemical processes that were used to produce the waste. In practice, however, this is impractical because of the numerous processes and process conditions that have been employed at the site during the many years of operation and because of the lack of post-process characterization data. Other factors, such as time/temperature/radiation effects can be highly variable and nearly impossible to duplicate in the laboratory. As an alternative to process simulation. the actual waste would be "fully" characterized for important chemical and physical properties. A waste simulant could then be defined, prepared, and characterized to determine how well its properties match those of the actual waste. However, because of the varied nature of the actual 
wastes and because of difficulties associated with representative sampling and precise characterization, simulants are often based on "best estimates" or "target" compositions of the actual wastes. Typical testing strategies also include simulant verification by conducting a limited number of tests with actual wastes.

Further difficulties encountered with producing representative simulants include cases where the waste streams cannot be defined because of unknown future process conditions, such as retrieval schemes and sequences. pretreatment operations, blending sequences, etc. In these cases, simulants are generally defined as an overall "volume-weighted" average composition based on a combination of waste tank analyses. waste volume projections. process knowledge, and/or other factors.

\section{GROUT DISPOSAL PROGRAM SIMULANTS}

Several DSTs have been sampled and characterized as part of an ongoing activity to determine the physical and chemical properties of the wastes stored at Hanford. Table 1 lists the concentration of some of the major species reported for eleven DSTs. . The compositions of some of these tanks served as the basis for defining "reference" compositions for use in developing simulants and grout waste forms. For example, a Double-Shell Slurry feed (DSSF) for use in grouting tests was based on analyses of tanks 241-AN-103 and 241-AW-101 (Claghorn 1987). Other simulants used in the GDP were based on the analyses of individual tanks, i.e.. tank 241-AN-106 and 241AP-102. Target compositions for the simulants representing these three wastes are shown in Table 2. The DSSF simulant composition was decreased by $50 \%$ from that reported in $\mathrm{Claghorn} \mathrm{(1987)} \mathrm{because} \mathrm{of} \mathrm{the} \mathrm{higher-than-allowable}$ concentration of heat-producing radionuclides (Hendrickson 1991). The data in Table 1 also illustrate the variability in reported concentrations of species for individual tanks. For example, the analyzed Na concentration in tank 241AW-101 ranges from 10 to 13.4 moles/L. These discrepancies, whether due to errors in sampling. inhomogenieties within the tank, sample preparation. analytical. or other factors. need to be addressed when preparing and testing simulants. . 
The effects of variability in the waste simulant compositions on grout properties have been reported (Hammitt and Welsh 1993. Lokken et al 1993. Lokken et a1 1987. Lokken and Martin 1992). The purpose of the waste compositional variability studies was to address the uncertainties associated with tank waste sampling and analyses and to define acceptable operating windows for which the grout process could produce acceptable waste forms. Another approach to waste variability was proposed in Anderson and Lokken (1993)(a) by including waste ions as variables in a statistically designed study for formulation development of grouts. The results of this study would have allowed the grout formulation (i.e.. dry blend component ratios) to be . tailored to a specific waste composition once detailed chemical analyses of a candidate waste tank were available. A statistically designed Composition Variation Study (CVS) was conducted at PNL for defining high-level waste glass compositions (Hrma and Piepel et al 1994)(b). This study, however, did not use waste simulants; rather, the waste constituents were added to the glass melts individually either as oxides or carbonates.

The simulants used for the GDP were generally solutions, because the GDP mission was to dispose of the liquid portion of the tank wastes. However, small quantities of solids were present in the tank waste samples and in the simulants, especially in the waste variability studies (Hammitt and Welsh 1993, Lokken et al 1993. Lokken et al 1987. Lokken and Martin 1992). The phosphate concent.ation in the simulants representing both the 241-AN-106 and 241-AP-102 tanks exceeded the sodium phosphate solubility limits at room temperature, necessitating maintaining the simulants at temperatures above $40^{\circ} \mathrm{C}$ to prevent crystallization. Aluminum hydroxide precipitates can also be formed when the $\mathrm{Al} / \mathrm{OH}$ ratio increases past one, either through intentional $\mathrm{pH}$ adjustments (Lokken 1992C) or by carbonation of the solutions.

(a) Anderson, C. M. and R. 0. Lokken. 1993. Iest Matrix for Grout Waste Envelode Study. HGTP-93-0307-01 (Draft), Pacific Northwest Laboratory. Richland, Wastington.

(b) Hrma, P. R. and G. F. Piepel. 1994. Property/Composition Relationships for Hanford High-Level Waste Glasses Melting at $1150^{\circ} \mathrm{C}$ PVTD-C95-02.01B, Pacific Northwest Laboratory, Richland. Washington. 
IABLE 1. Reported Concentrations of Select Major Species in Double-Shell Tank Wastes

\begin{tabular}{|c|c|c|c|c|c|c|}
\hline & Reported & (Analyzed & Conc & tratio & $1 . M / L$ & \\
\hline Tank. & Al & $\mathrm{Na}$ & $\mathrm{NO}_{2}$ & $\mathrm{NO}_{3}$ & $\mathrm{OH}$ & References \\
\hline $241-A N-103$ & 2.5 & 13 & 2.2 & 3.5 & 5.7 & Hendrickson (1990) \\
\hline $24 I-A N-103$ & 1.5 & 12.9 & 3.29 & 2.94 & 5.6 & Claghorn (1987) \\
\hline $241-A N-103$ & 2.13 & 14.6 & 2.99 & 2.58 & 5.74 & Shade (1994) \\
\hline $241-A N-104$ & 1.6 & 11.2 & 2 & 3 & 4 & Hendrickson (1990) \\
\hline $241-A N-104$ & 1.39 & 12 & 1.92 & 3.1 & 4.09 & Shade (1994) \\
\hline $241-A N-105$ & 1.74 & 12 & 2.61 & 3.12 & 3.64 & Shade (1994) \\
\hline $241-A N-106$ & 0.39 & 5.3 & 0.73 & 1.3 & 0.71 & Hendrickson (1990) \\
\hline $241-A N-106$ & 0.4 & 4.1 & 0.83 & 1.43 & & Serne et al. (1989) \\
\hline $241-A N-106$ & 0.46 & 5.3 & 0.8 & 1.45 & 1.35 & Serne et a1. (1989) \\
\hline $241-A N-106$ & 0.344 & 3.93 & 0.644 & 1.1 & 0.474 & Shade (1994) \\
\hline $241-A P-102$ & 0.43 & 4.4 & 0.78 & 1.22 & 0.54 & Welsh (1994a) \\
\hline $241-A P-105$ & 043 & 7.3 & 1.05 & 2.69 & 3.17 & Welsh (1994b) \\
\hline $241-A P-105$ & 0.16 & 6.35 & 1.09 & 2.66 & 4.63 & Shade (1994) \\
\hline $241-A P-106$ & 0.008 & 0.24 & 0.03 & 0.07 & 0.08 & Welsh (1994C) \\
\hline $241-A W-101$ & 0.94 & 11 & 1.8 & 4.6 & 5.8 & Hendrickson (1990) \\
\hline $241-A W-101$ & 1.03 & 10 & 2.16 & 3.46 & 5.07 & Hendrickson (1991) \\
\hline $241-A W-101$ & 1.29 & 13.4 & 2.28 & 3.62 & 4.73 & Hendrickson (1991) \\
\hline $241-A W-101$ & 1.14 & 13 & 1.82 & 4.22 & 5.45 & Claghorn (1987) \\
\hline $241-A W-101$ & 1.03 & 10 & 2.19 & 3.46 & 5.07 & Shade (1994) \\
\hline $241-A W-102$ & 1.9 & 10.4 & 1.7 & 2.8 & 4.8 & Hendrickson (1990) \\
\hline $241-A W-106$ & 1.9 & 11.1 & 3.1 & 2.8 & 3.1 & Hendrickson (1990) \\
\hline $241-S Y-101$ & 1.7 & 12.6 & 2.4 & 2.5 & 2 & Hendrickson (1990) \\
\hline
\end{tabular}


IABLE 2. Target Compositions of Double-Shell Tank Simulants Used for the Grout Disposal Program

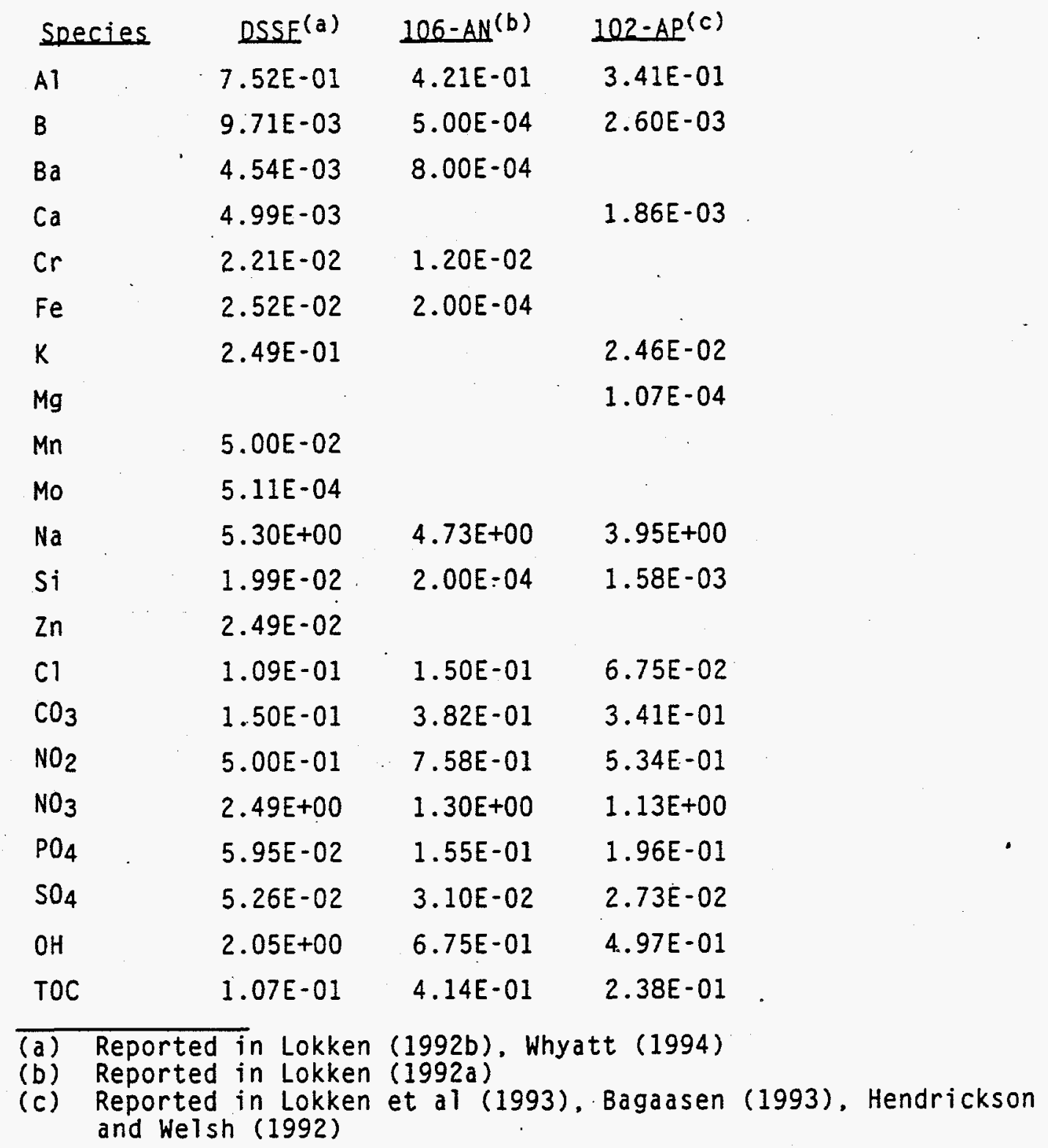

Work with simulants is more convenient and often necessary because of costs or hazards associated with using actual radioactive wastes. This is especially true when large volumes of wastes are required. For the GDP. more than $75.000 \mathrm{~L}$ of simulated PSW waste (Fow et al. 1987). 10.000 L of simulated DSSF (Whyatt 1994), and 13,000 L of simulated 106-AN waste (Bagasen 1993) have been prepared and used in pilot-scale and laboratory studies at PNL. 
Simulants also allow for the determination of leach rates of low-activity radionuclides, when their presence would be masked by the higher-activity radionuclides (Serne 1992 ).

\section{LLW VITRIFICATION SIMULANTS}

For the first phase of LLW vitrification simulant development, two waste compositions were investigated. The simulated wastes were based on the analyses of six tanks of DSSF waste and on the projected composition of the wastes exiting the pretreatment operations (Shade 1994). A simulant normalized to $6 \underline{M}$ sodium was based on the anticipated concentration after ion exchange and initial separations. A $10 \mathrm{M}$ sodium simulant would represent a waste that has been concentrated by evaporation to reduce the overall volume. Development and characterization of this simulant is described in the following sections.

A third LLW simulant, referred to as the remaining inventory, included wastes not included in the DSSF tanks and the projected LLW fraction of single-shell tank wastes (Shade 1994). This waste was originally to be used in the second phase of melter system testing. Additional simulant compositions will be developed and tested as retrieval sequences. blending strategies, and pretreatment flowsheets become finalized. 


\section{LABORATORY OEVELOPMENT OF LLW VITRIFICATION SIMULANT}

Laboratory tests were conducted to develop procedures that could be used for producing large quantities of LLW simulant for use in the melter vendor tests and in various laboratory studies. Simulants were prepared with reagent-grade chemicals to obtain the ionic concentrations listed in Table 3 . The target values in Table 3 are estimated from the projected compositions of LLW discharged from the pretreatment and separation processes and from the initial characterization data for the starting waste compositions reported by Hendrickson and Conner (1994). The concentrations of several species (i.e. Mo, $\mathrm{Sr}, \mathrm{Cs}$, and $\mathrm{IO}_{4}$ ) have been set higher than analyzed in order to monitor their behavior during vitrification. Molybdenum was used as a stand-in for technetium in these studies because of their similar chemical characteristics.

For each of the three simulants listed in Table 3. two solutions were prepared - one containing the acid-soluble compounds and the other containing the alkaline or neutral compounds. The final simulants were prepared by adding the acid solution to the alkaline solution. Separate acid and alkaline solutions were studied because it was not known whether significant quantities of precipitates would be present in the final simulant that would result in difficulties in providing a uniform feed to the melters.

The compounds and their concentrations used to prepared each of the three simulants are listed in Tables 4 through 6 . The acid and alkaline compounds were added (in the order listed in the tables) to approximately $300 \mathrm{ml}$ of water in a polypropylene jar. The solutions/slurries were constantly agitated during the chemical addition. The solutions/slurries were not heated during preparation; any temperature changes were from the heat of solution of the salts. After all the chemicals had been added, the solution/slurry was transferred to a graduated cylinder and the volume adjusted to $500 \mathrm{mi}$ (for the acid and alkaline portions of each of the simulants). The densities of the solutions were then determined from the weight of $500 \mathrm{ml}$ of solution. Final simulants were prepared by adding equal volumes of the acid components to the alkaline components. The simulant mixtures were constantly agitated until no more solids dissolved. 
IABLE 3. Target Concentrations of Low-Level Waste Simulants for Vitrification Development. moles/L

\begin{tabular}{|c|c|c|c|}
\hline Component & $\begin{array}{l}\text { DSSF } \\
6 \stackrel{M}{M} \mathrm{Na}\end{array}$ & $\begin{array}{c}\text { DSSF } \\
10 \mathrm{M} \mathrm{Na}\end{array}$ & $\begin{array}{l}\text { Remaining } \\
\text { Inventory }\end{array}$ \\
\hline Al & 0.61 & 1.02 & 0.16 \\
\hline $\mathrm{Ca}$ & 0.00063 & 0.00105 & 0.0004 \\
\hline $\mathrm{Cr}$ & 0.0052 & 0.00867 & 0.0042 \\
\hline $\mathrm{Fe}$ & 0.00046 & 0.000767 & 0.00024 \\
\hline K & 0.30 & 0.50 & 0.0058 \\
\hline $\mathrm{Mg}$ & 0.00062 & 0.00103 & 0.0000011 \\
\hline Mn & 0.00025 & 0.000417 & 0.001 \\
\hline Mo & 0.01 & 0.0167 & 0.01 \\
\hline $\mathrm{Na}$ & 6.0 & 10.0 & 6.0 \\
\hline $\mathrm{Sr}$ & 0.01 & 0.0167 & 0.01 \\
\hline Cs & 0.01 & 0.0167 & 0.01 \\
\hline $\mathrm{PO}_{4}$ & 0.026 & 0.0433 & 0.11 \\
\hline $\mathrm{IO}_{3}$ & 0.01 & 0.0167 & 0.01 \\
\hline $\mathrm{CO}_{3}$ & 0.16 & 0.267 & 0.05 \\
\hline $\mathrm{Cl}$ & 0.096 & 0.127 & 0.0092 \\
\hline$F$ & 0.15 & 0.25 & 0.13 \\
\hline $\mathrm{SO}_{4}$ & 0.026 & 0.0433 & 0.038 \\
\hline $\mathrm{NO}_{3}$ & 1.9 & 3.11 & 3.5 \\
\hline $\mathrm{NO}_{2}$ & 1.0 & 1.67 & 0.26 \\
\hline $\mathrm{OH}$ & 2.3 & 3.8 & 1.5 \\
\hline TOC. & 0.81 & 1.35 & 0.11 \\
\hline
\end{tabular}


IABLE 4. Recipe for DSSF Vitrification Simulant Normalized to $6 \mathrm{M} \mathrm{Na}$

\begin{tabular}{|c|c|c|}
\hline Compound & $M / L$ & $g / L$ \\
\hline $\mathrm{A} 1\left(\mathrm{NO}_{3}\right) 3 \cdot 9 \mathrm{H}_{2} \mathrm{O}$ & 0.61 & 228.84 \\
\hline $\mathrm{Ca}\left(\mathrm{NO}_{3}\right)_{2} \cdot 4 \mathrm{H}_{2} \mathrm{O}$ & 0.00063 & 0.15 \\
\hline $\mathrm{Cr}\left(\mathrm{NO}_{3}\right)_{3} \cdot 9 \mathrm{H}_{2} \mathrm{O}$ & 0.0052 & 2.08 \\
\hline $\mathrm{Fe}\left(\mathrm{NO}_{3}\right)_{3} \cdot 9 \mathrm{H}_{2} \mathrm{O}$ & 0.00046 & 0.19 \\
\hline $\mathrm{Mg}\left(\mathrm{NO}_{3}\right)_{2} \cdot 6 \mathrm{H}_{2} \mathrm{O}$ & 0.00062 & 0.16 \\
\hline $\mathrm{Mn}\left(\mathrm{NO}_{3}\right)_{2}\left(50 \% \mathrm{sol}^{\prime} \mathrm{n}\right)$ & 0.00025 & 0.0447 \\
\hline $\mathrm{Na}_{2} \mathrm{MOO}_{4} \cdot \mathrm{H}_{2} \mathrm{O}$ & 0.01 & 2.42 \\
\hline $\mathrm{CsNO}_{3}$ & 0.01 & 1.95 \\
\hline $\mathrm{Na}_{4}$ EDTA & 0.081 & 33.71 \\
\hline $\begin{array}{r}\text { Total Acidic } \\
\text { Compounds }\end{array}$ & & 269.54 \\
\hline $\mathrm{NaNO}_{2}$ & 1 & 69.00 \\
\hline $\mathrm{KOH}$ & 0.3 & 16.83 \\
\hline $\mathrm{SrCi}_{2} \cdot 6 \mathrm{H}_{2} \mathrm{O}$ & 0.01 & 2.67 \\
\hline $\mathrm{NaH}_{2} \mathrm{PO}_{4} \cdot \mathrm{H}_{2} \mathrm{O}$ & $0: 026$ & 3.59 \\
\hline $\mathrm{NaIO}$ & 0.01 & 1.98 \\
\hline $\mathrm{Na}_{2} \mathrm{CO}_{3}$ & 0.16 & 16.96 \\
\hline $\mathrm{NaCl}$ & 0.076 & 4.44 \\
\hline $\mathrm{NaF}$ & 0.15 & 6.30 \\
\hline $\mathrm{Na}_{2} \mathrm{SO}_{4}$ & 0.026 & 3.69 \\
\hline $\mathrm{NaOH}$ (pellets) & 4 & 160.00 \\
\hline $\begin{array}{l}\text { Total Alkaline } \\
\text { Compounds }\end{array}$ & & 285.46 \\
\hline
\end{tabular}


IABLE 5. Recipe for DSSF Vitrification Simulant Normalized to $10 \mathrm{M} \mathrm{Na}$

\begin{tabular}{|c|c|c|}
\hline Compound & $M / L$ & $g / L$ \\
\hline $\mathrm{A} 1\left(\mathrm{NO}_{3}\right) 3 \cdot 9 \mathrm{H}_{2} \mathrm{O}$ & $1.02 \mathrm{E}+00$ & 381.39 \\
\hline $\mathrm{Ca}\left(\mathrm{NO}_{3}\right)_{2} \cdot 4 \mathrm{H}_{2} \mathrm{O}$ & $1.05 E-03$ & 0.25 \\
\hline $\mathrm{Cr}\left(\mathrm{NO}_{3}\right)_{3} \cdot 9 \mathrm{H}_{2} \mathrm{O}$ & $8.67 E-03$ & 3.47 \\
\hline $\mathrm{Fe}\left(\mathrm{NO}_{3}\right)_{3} \cdot 9 \mathrm{H}_{2} \mathrm{O}$ & $7.67 E-04$ & 0.31 \\
\hline $\mathrm{Mg}\left(\mathrm{NO}_{3}\right)_{2} \cdot 6 \mathrm{H}_{2} \mathrm{O}$ & $1.03 E-03$ & 0.26 \\
\hline $\operatorname{Mn}\left(\mathrm{NO}_{3}\right)_{2}(50 \% \mathrm{sol} \cdot n)$ & $4.17 E-04$ & 0.0746 \\
\hline $\mathrm{Na}_{2} \mathrm{MOO}_{4} \cdot \mathrm{H}_{2} \mathrm{O}$ & $1.67 E-02$ & 4.03 \\
\hline $\mathrm{CsNO}_{3}$ & $1.67 E-02$ & 3.25 \\
\hline $\mathrm{Na}_{4}$ EDTA & $1.35 E-01$ & 56.19 \\
\hline $\begin{array}{r}\text { Total Acidic } \\
\text { Compounds }\end{array}$ & & 449.23 \\
\hline $\mathrm{NaNO}_{2}$ & $1.67 E+00$ & 115.00 \\
\hline $\mathrm{KOH}$ & $5.00 E-01$ & 28.05 \\
\hline $\mathrm{SrCl}_{2} \cdot 6 \mathrm{H}_{2} \mathrm{O}$ & $1.67 E-02$ & 4.44 \\
\hline $\mathrm{NaH}_{2} \mathrm{PO}_{4} \cdot \mathrm{H}_{2} \mathrm{O}$ & $4.33 E-02$ & 5.98 \\
\hline $\mathrm{NaIO}$ & $1.67 E-02$ & 3.30 \\
\hline $\mathrm{Na}_{2} \mathrm{CO}_{3}$ & $2.67 E-01$ & 28.27 \\
\hline $\mathrm{NaCl}$ & $1.27 E-01$ & 7.40 \\
\hline $\mathrm{NaF}$ & $2.50 E-01$ & 10.50 \\
\hline $\mathrm{Na}_{2} \mathrm{SO}_{4}$ & $4.33 E-02$ & 6.16 \\
\hline $\mathrm{NaOH}$ (pellets) & $6.67 E+00$ & 266.67 \\
\hline $\begin{array}{l}\text { Total Alkaline } \\
\text { Compounds }\end{array}$ & & 475.76 \\
\hline
\end{tabular}


TABLE 6. Recipe for Remaining Inventory Vitrification Simulant Normalized to $6 \mathrm{M} \mathrm{Na}$

\begin{tabular}{|c|c|c|}
\hline Compound & $M / L$ & $g / L$ \\
\hline $\mathrm{A}]\left(\mathrm{NO}_{3}\right) 3 \cdot 9 \mathrm{H}_{2} \mathrm{O}$ & 0.16 & 60.02 \\
\hline $\mathrm{Ca}\left(\mathrm{NO}_{3}\right)_{2} \cdot 4 \mathrm{H}_{2} \mathrm{O}$ & $4.00 E-04$ & 0.09 \\
\hline $\mathrm{Cr}\left(\mathrm{NO}_{3}\right)_{3} \cdot 9 \mathrm{H}_{2} \mathrm{O}$ & $4.20 E-03$ & 1.68 \\
\hline $\mathrm{Fe}\left(\mathrm{NO}_{3}\right)_{3} \cdot 9 \mathrm{H}_{2} \mathrm{O}$ & $2.40 E-04$ & 0.10 \\
\hline $\mathrm{Mg}\left(\mathrm{NO}_{2}\right)_{2} \cdot 6 \mathrm{H}_{2} \mathrm{O}$ & $1.10 E-06$ & 0.0003 \\
\hline $\mathrm{Mn}\left(\mathrm{NO}_{3}\right)_{2}(50 \%$ sol' $\mathrm{n})$ & $1.00 \mathrm{E}-03$ & 0.1789 \\
\hline $\mathrm{Na}_{2} \mathrm{MOO}_{4} \cdot \mathrm{H}_{2} \mathrm{O}$ & 0.01 & 2.42 \\
\hline $\mathrm{CsNO}_{3}$ & 0.01 & 1.95 \\
\hline $\mathrm{NaNO}_{3}$ & 3 & 255.00 \\
\hline $\mathrm{Sr}\left(\mathrm{NO}_{3}\right)_{2}$ & 0.01 & 2.12 \\
\hline $\mathrm{Na} 4$ EDTA & 0.011 & 4.58 \\
\hline $\begin{array}{r}\text { Total Acidic } \\
\text { Compounds }\end{array}$ & & $\overline{328.14}$ \\
\hline $\mathrm{NaNO}_{2}$ & 0.26 & 17.94 \\
\hline $\mathrm{KOH}$ & $5.80 E-03$ & 0.33 \\
\hline $\mathrm{NaH}_{2} \mathrm{PO}_{4} \cdot \mathrm{H}_{2} \mathrm{O}$ & 0.11 & $15: 18$ \\
\hline $\mathrm{NaIO}$ & 0.01 & 1.98 \\
\hline $\mathrm{Na}_{2} \mathrm{CO}_{3}$ & 0.05 & 5.30 \\
\hline $\mathrm{NaCl}$ & $9.20 \mathrm{E}-03$ & 0.54 \\
\hline $\mathrm{NaF}$ & 0.13 & 5.46 \\
\hline $\mathrm{Na}_{2} \mathrm{SO}_{4}$ & 0.038 & 5.40 \\
\hline $\mathrm{NaOH}(50 \% \cdot \mathrm{SO} / \mathrm{n})$ & 2.2 & 176.00 \\
\hline $\begin{array}{l}\text { Total Alkaline } \\
\text { Compounds }\end{array}$ & & $\overline{228.12}$ \\
\hline
\end{tabular}




\section{RECOMMENDED PROCEDURE FOR LLW SIMULANT PREPARATION}

The following procedure was recommended for preparing $10 M$ simulated $L L W$ for use in laboratory studies and for the Phase I melter vendor tests (Lokken and Martin 1994, Shade 1994). Preparation of a single solution was recommended because of the larger amount of solids present in the separate acid and alkaline solutions.

Start with water at approximately 60 vol\% of the final solution volume required. Add the appropriate amounts of the following compounds in the order listed to the water while maintaining constant agitation (note: the solution may be heated to approximately $60^{\circ} \mathrm{C}$ to aid dissolution):

\begin{tabular}{lc} 
Compound & $g / L$ \\
\hline $\mathrm{NaNO}_{2}$ & 115 \\
$\mathrm{KOH}$ & 28.1 \\
$\mathrm{SrCl}_{2} \cdot 6 \mathrm{H}_{2} \mathrm{O}$ & 4.44 \\
$\mathrm{NaH}_{2} \mathrm{PO}_{4} \cdot \mathrm{H}_{2} \mathrm{O}$ & 5.98 \\
$\mathrm{NaIO}$ & 3.30 \\
$\mathrm{Na}_{2} \mathrm{CO}_{3}$ & 28.3 \\
$\mathrm{NaCl}$ & 7.40 \\
$\mathrm{NaF}$ & 10.5 \\
$\mathrm{Na} 2 \mathrm{SO}_{4}$ & 6.16 \\
$\mathrm{NaOH}$ & 266 \\
$\mathrm{~A}\left(\mathrm{NO}_{3}\right)_{3} \cdot 9 \mathrm{H}_{2} \mathrm{O}$ & 381 \\
$\mathrm{Ca}\left(\mathrm{NO}_{3}\right)_{2} \cdot 4 \mathrm{H}_{2} \mathrm{O}$ & 0.25 \\
$\mathrm{Cr}\left(\mathrm{NO}_{3}\right)_{3} \cdot 9 \mathrm{H}_{2} \mathrm{O}$ & 3.47 \\
$\mathrm{Fe}\left(\mathrm{NO}_{3}\right)_{3} \cdot 9 \mathrm{H}_{2} \mathrm{O}$ & 0.31 \\
$\mathrm{Mg}\left(\mathrm{NO}_{3}\right)_{2} \cdot 6 \mathrm{H}_{2} \mathrm{O}$ & 0.26 \\
$\mathrm{Mn}\left(\mathrm{NO}_{3}\right)_{2}$ & 0.075 \\
$\mathrm{Na} 2 \mathrm{MOO}_{4} \cdot \mathrm{H}_{2} \mathrm{O}$ & 4.03 \\
$\mathrm{CsNO}$ & 3.25 \\
$\mathrm{Na} 4 \mathrm{NDTA}_{3}$ & 56.2 \\
&
\end{tabular}




\section{SIMULANT PREPARATION FOR MELTER VENDOR TESTS}

Three batches of a nominal $10 \mathrm{M}$ Na LLW simulant were prepared at optima Chemical Company (Optima) for use in the Phase I melter vendor tests. A total of about 42,000 liters were prepared. A 945-1iter batch of simulant was also prepared at PNL for use in pilot-scale tests in support of the melter vendor tests (See Appendix A). The quantities of chemicals used for the production of these simulants are shown in Table 7. Several of the compounds specified. in the recommended procedure (Lokken and Martin 1994) were substituted with solutions because the solid compounds were not commercially available (See Table 7 footnotes).

The simulants prepared at optima were prepared in three batches. The first two batches were supposed to be 13.230 liters each, and the third was 15.540 liters. The following discussion summarizes procedures used at Optima as discussed in the trip reports.

\section{OPTIMA CHEMICAL - BATCH 1 (a)}

Two solutions, a basic and an acidic solution. were prepared for the first batch of simulant. The basic solution maintained a chalky white appearance throughout the chemical additions. The acidic solution was clear after adding the $\mathrm{Al}\left(\mathrm{NO}_{3}\right)_{3}$ and then turned to a milky green after all the chemicals had been added. Prior to adding the acidic solution to the basic solution, the basic solution was recirculated through a heat exchanger that kept the solution around $52^{\circ} \mathrm{C}$. As the acidic solution was added to the basic solution, a foam layer formed near the center of the solution surface and the layer eventuaily grew to cover about $75 \%$ of the surface. The color of the resulting solution turned from milky white to milky gray and finally to milky deep olive green.

After the two solutions had been prepared. it was recognized that the combined volumes of the two solutions would exceed the desired final volume of

(a) Optima Trip Report - Observe LLW (DSSF) Simulant Preparation. August 16. 1994. Internal Memo from Regan Seymour to Vitrification Development. Westinghouse Hanford Company, Richland, Washington. 
simulant; i.e.. -13.200 liters. The overage was attributed to a miscalculation in the volume of the $\mathrm{Al}\left(\mathrm{NO}_{3}\right)_{3}$ and NaEDTA solutions added to the acidic solution. Several options to recover the simulant concentration were discussed and it was agreed that the current batch of simulant would be split in half. To one of the halves, the basic chemicals for the second simulant batch would be added but using solid $\mathrm{NaOH}$ flake instead of the $50 \%$ solution. The acidic solution for the second batch would be made in a separate tank and added to the basic solution. The remaining half of the first batch would then be recirculated with the other half of the first batch containing the second batch acidic and basic materials to form the final simulant.

\section{OPTIMA CHEMICAL - BATCH $2^{(a)}$}

Approximately 8300 liters of the Batch 1 simulant was transferred to a 17.000-liter storage tank (ST1), leaving about 7500 liters in the original tank (Tank A). The acidic solution was prepared in a second 17,000-1iter tank (Tank B). The resulting solution turned a dark violet color over time and the volume was 6800 liters. The basic solution was prepared in the original tank which contained simulant from Batch 1 . After addition of all the chemicals, the volume was $-10,600$ liters and the solution was a milky olive green color. The acidic solution in Tank $B$ was slowly added to the basic solution in Tank A. After all of the solution was added. Tank A contained $-17,400$ liters of simulant, having a deep olive green color.

The simulants from Batches 1 and 2 were then mixed. One half of the contents of Tank $A$ was transferred to Tank $B$ and the solution in Tank STI was transferred into Tanks $A$ and $B$ in roughly equal proportions. Approximately 230 liters of wash water and 1625 liters of additional makeup water were added to Tank $A$ to achieve the desired 26,460 liters of mixed simulant. The two tanks were valved to allow withdrawal from the bottom of each tank by a single pump. The solutions were mixed at the pump and transferred to the top of each tank in two relatively equal streams. After mixing for 3 hours, seven samples were taken for analyses.

(a) Optima Trip Report - Batch 非, August 24, 1994. Internal Memo from Eric Slaathaug to E. T. Weber. Westinghouse Hanford Company, Richland. Washington. 
OPTIMA CHEMICAL - BATCH $3^{(a)}$

The acidic solution for Batch 3 was prepared by adding the chemicals (mostly in the form of solutions) to a 18.900-ijter tank. The solution was a clear yellow color after addition of $\mathrm{Al}\left(\mathrm{NO}_{3}\right)_{3}$ and turned to a milky green at the end of the acid chemical additions. After sampling. the color of the solution appeared to be milky purple, rather than the green color seen in the tank.

The basic solution was also prepared in a 18,900-liter tank. The basic chemicals except for $\mathrm{NaNO}_{2}$ and $\mathrm{NaOH}$ were added to 1500 liters of water. After finding a ring of solids around the tank, an additional 750 liters of water were added before adding the $\mathrm{NaNO}_{2}$ and $\mathrm{NaOH}$. The $\mathrm{NaNO}_{2}$ was added, and as the $\mathrm{NaOH}$ was added, the viscosity of the solution decreased until about $65 \%$ of the $\mathrm{NaOH}$ had been added. At this point. the solution quickly gelled. resulting in a sticky solid salt cake that froze the agitator. Addition of small quantities of the acid solution and manual mixing were required to dissolve the basic solution around the agitator. After about 1500 liters of acid solution were added incrementally to the basic solution, the acid solution was added slowly and continuously until about half ( 3800 liters) had been added. Acid additions were then stopped because of high temperatures within the tank.

After the basic solution had cooled overnight, the remaining $\mathrm{NaOH}$ and acid solution were added. During the acid addition, a 15 - to $20-\mathrm{cm}$ thick foam formed on the surface of the solution which eventually increased in thickness up to $\sim 46 \mathrm{~cm}$. Spraying the remaining acid solution onto the foam broke up the layer. with a release of $\mathrm{NO}_{\mathrm{x}}$, and allowed a continuous addition until all the acid solution had been added.

(a) Optima Trip Report - Observe DSSF Simulant Preparation: 3rd Batch. August 16, 1994, DSI from R. G. Seymour to E. T. Weber. Westinghouse Hanford Company. Richland, Washington. 
TABLE 7. Batch Sheet for Preparation of $10 \underline{M} \mathrm{Na}$ LLW Simulant at Optima Chemical for Melter Vendor Tests and at PNL for a Pilot-Scale Test. (See Appendices A, B, and C)

\begin{tabular}{|c|c|c|c|c|c|}
\hline \multirow[b]{3}{*}{ Compound } & \multirow[b]{3}{*}{$\begin{array}{c}\text { Moles/ } \\
\text { Liter } \\
\end{array}$} & \multicolumn{3}{|c|}{ Optima Chemical } & \multirow{3}{*}{$\frac{\text { PNL }}{\frac{\text { Pilot-Scale }}{\mathrm{kg} / 945 \mathrm{~L}}}$} \\
\hline & & \multicolumn{2}{|c|}{ Batches 182} & \multirow{2}{*}{$\begin{array}{r}\text { Batch } 3 \\
\mathrm{~kg} / \\
15.540^{\prime} \mathrm{L}\end{array}$} & \\
\hline & & $\begin{array}{r}\mathrm{kg} / \\
13,230 \mathrm{~L} \\
\end{array}$ & $\begin{array}{r}\mathrm{kg} / \\
13,230^{\mathrm{L}} \mathrm{L} \\
\end{array}$ & & \\
\hline $\mathrm{Al}\left(\mathrm{NO}_{3}\right)_{3} \cdot 9 \mathrm{H}_{2} \mathrm{O}(\mathrm{a})$ & 1.02 & 5084.09 & 5083.36 & 5950.80 & 383.5 \\
\hline $\mathrm{Ca}\left(\mathrm{NO}_{3}\right)_{2} \cdot 4 \mathrm{H}_{2} \mathrm{O}^{(\mathrm{b})}$ & 0.001 & 3.15 & 3.15 & 3.66 & 0.23 \\
\hline $\mathrm{Cr}\left(\mathrm{NO}_{3}\right)_{3} \cdot 9 \mathrm{H}_{2} \mathrm{O}(\mathrm{c})$ & 0.0087 & 6.00 & 6.02 & 7.04 & 3.27 \\
\hline $\mathrm{Fe}\left(\mathrm{NO}_{3}\right)_{3} \cdot 9 \mathrm{H}_{2} \mathrm{O}(\mathrm{d})$ & 0.00077 & 0.58 & 0.57 & 0.67 & 0.29 \\
\hline $\mathrm{KOH}$ & 0.5 & 372.49 & 372.49 & 436.28 & 26.40 \\
\hline $\left.\mathrm{Mg}\left(\mathrm{NO}_{3}\right)_{2}\right)_{2} \cdot 6 \mathrm{H}_{2} \mathrm{O}^{(\mathrm{e})}$ & 0.001 & 3.42 & 3.39 & 3.99 & 0.25 \\
\hline $\mathrm{Mn}\left(\mathrm{NO}_{3}\right)_{2}$ & 0.00042 & 1.00 & 0.98 & 1.16 & 0.07 \\
\hline $\mathrm{Na}_{2} \mathrm{MOO}_{4} \cdot \mathrm{H}_{2} \mathrm{O}$ & 0.017 & 54.63 & 54.63 & 25.35 & 3.80 \\
\hline $\mathrm{SrCl}_{2}$ & 0.017 & 35.81 & 35.81 & 41.92 & 2.49 \\
\hline $\mathrm{CsNO}_{3}$ & 0.017 & 44.00 & 44.00 & 51.53 & 3.06 \\
\hline $\mathrm{NaH}_{2} \mathrm{PO}_{4} \cdot \mathrm{H}_{2} \mathrm{O}$ & 0.043 & 68.51 & 68.51 & 80.27 & 5.62 \\
\hline $\mathrm{NaIO}_{3}$ & 0.017 & 44.91 & 44.91 & 52.31 & 3.11 \\
\hline $\mathrm{Na}_{2} \mathrm{CO}_{3}$ & 0.27 & 380.07 & 380.07 & 440.70 & 26.59 \\
\hline $\mathrm{NaCl}$ & 0.13 & 97.83 & 97.83 & 114.57 & 6.97 \\
\hline $\mathrm{NaF}$ & 0.25 & 139.44 & 139.44 & 163.34 & 9.89 \\
\hline $\mathrm{Na}_{2} \mathrm{SO}_{4}$ & 0.043 & 81.14. & 81.14 & 95.02 & 5.80 \\
\hline $\mathrm{NaNO}_{2}$ & 1.7 & 1557.74 & 1557.74 & 1824.45 & 108.23 \\
\hline $\mathrm{NaOH}$ & 6.7 & $3559.71(f)$ & 3559.09 & 4168.43 & $125.45^{(g)}$ \\
\hline $\mathrm{Na}_{4}$ EDTA & 1.4 & $707.01^{(h)}$ & & . & 52.88 \\
\hline $\mathrm{Na}_{4}$ EDTA $2 \mathrm{H}_{2} \mathrm{O}$ & 1.4 & & 706.88 & 827.89 & \\
\hline
\end{tabular}

(a) Added as a 60 wt\% solution

(b) Added as a $66 \mathrm{wt} \%$ solution

(c) Added as a 9.7 wt\% Cr solution

(d) Added as a 10.5 wt\% Fe solution

(e) Added as a $66 \mathrm{wt} \%$ solution

(f) Added as a 50 wt\% solution

(g) This quantity is half the amount required. Adjustments were made when glass formers were added (See Appendix A)

(h) Added as a $38 \mathrm{wt} \%$ solution 
PVTD-C95-02.03J

\section{CHARACTERIZATION}

This section describes the tests that were conducted on the LLW simulants and the data collected to determine the quantity of settled solids, density. viscosity, water content, and chemical composition. Where data were reported on other simulants or actual waste, these are also included in the tables.

\section{SETTLED SOLIOS}

The quantity of settled solids from the LLW vitrification simulant laboratory studies was estimated by allowing the freshly prepared solutions to remain undisturbed in a closed container until a clear supernate was observed and then estimating the total volume of solids by comparing the depth of solids to the total depth of sample. The two alkaline. DSSF samples contained fairly large quantities of gelatinous solids (Lokken and Martin 1994). However. when mixed with their respective acid solutions, the total amount of solids was reduced to less than 5 vol\%. The reduction in the solids content was likely because of the two-fold decrease in the overall concentration in the final solution.

The settling rates of the solids were very slow for the $6 \underline{M}$ and $10 \mathrm{M} \mathrm{Na}$ DSSF, requiring several hours for a clear supernate to be seen. The remaining inventory (RI) simulant contained some light-colored undissolved solids that settled out rapidiy (i.e.. within minutes); and a finer, darker fraction that resembled the solids in the two DSSF simulants. Table 8 summarizes the estimated amount of settled solids for the laboratory-produced simulants, and from the PNL melter test and melter vendor test simulants.

An important property of slurries is the ability to resuspend the solids once they have settled to obtain a uniform feed to the vitrification facility. A qualitative evaluation of the "resuspendability" of the solids in the three laboratory-prepared simulants was done by allowing the solids to settle in a Tefion bottle overnight and then slowly turning the bottles end-over-end several times, each time inspecting the bottom for the presence of remaining solids. The solids in the $6 . M$ and $10 M \mathrm{Na}$ DSSF simulants and the finer, dark solids in the remaining inventory simulant were easily resuspended during the 
first couple rotations of the bottles. The lighter-colored solids in the remaining inventory sample appeared gelatinous and "dripped" from the bottom when the bottle was inverted. After about five rotations of the bottle, all the solids were resuspended. Based on these observations, it appears that the solids in all the simulants could be easily resuspended by moderate agitation.

IABLE 8. Estimated Volume Percent Settled Solids After 24 Hours for LLW Vitrification Simulants

\begin{tabular}{|c|c|}
\hline Simulant & Mixture \\
\hline DSSF, $6 \mathrm{M} \mathrm{Na(a)}$ & $<3$ \\
\hline DSSF, $10 \mathrm{M} \mathrm{Na}(a)$ & $<5$ \\
\hline $\mathrm{RI}, 6 \mathrm{MNa}(\mathrm{a})$ & 10 \\
\hline DSSF. $10 \mathrm{M} \mathrm{Na}(b)$ & 3.0 \\
\hline DSSF. $10 \mathrm{M} \mathrm{Na}(\mathrm{c})$ & 2.7 \\
\hline
\end{tabular}

(a) Simulants prepared in the laboratory

(b) Simulant from PNL small-scale test (See Appendix A)

(c) Batch 1 and 2 of Optima Chemical's simulant (See Appendix B).

\section{DENSITY}

Densities of the solutions/slurries were measured by weighing a known volume of the simulants. Table 9 summarizes the results of density determinations on the LLW vitrification simulants and reported values for tank waste samples and GDP simulants (note: the densities were either measured at ambient temperature, or the temperature was not reported). 
IABLE 9. Densities of Simulated or Actual Wastes

\begin{tabular}{|c|c|}
\hline Simulant/Waste & Density, $\mathrm{g} / \mathrm{cm}^{3}$ \\
\hline DSSF, $6 \mathrm{M} \mathrm{Na}$ & 1.31 \\
\hline DSSF, $10 \mathrm{M} \mathrm{Na}$ & 1.42 \\
\hline $\mathrm{RI}, 6 \mathrm{M} \mathrm{Na}$ & 1.28 \\
\hline DSSF, $10 \mathrm{M} \mathrm{Na(a)}$ & 1.38 \\
\hline DSSF, $10 \mathrm{M} \mathrm{Na}^{(b)}$ & 1.45 \\
\hline DSSF, $10 \mathrm{M} \mathrm{Na}(c)$ & 1.50 \\
\hline $241-A N-106^{(d)}$ & 1.23 \\
\hline $241-A N-106^{(e)}$ & 1.20 \\
\hline $241-A W-101^{(d)}$ & 1.56 \\
\hline $241-A P-105^{(d)}$ & 1.35 \\
\hline $241-A P-105^{(g)}$ & 1.336 \\
\hline $241-A N-104^{(d)}$ & 1.50 \\
\hline $241-A R-105^{(d, e)}$ & 1.50 \\
\hline $241-A N-103^{(d, e)}$ & 1.60 \\
\hline $241-A N-102^{(f)}$ & 1.2001 \\
\hline $241-A P-106^{(h)}$ & 0.9961 \\
\hline DSSF (GDP) & 1.293 \\
\hline
\end{tabular}

(a) Simulant from PNL pilot-scale test (See Appendix A).

(b) Batch 1 and 2 of Optima Chemical's Simulant (See Appendix B).

(c) Batch 3 of Optima Chemical's Simulant (See Appendix C).

(d) Reported in Shade (1994).

(e). Reported in Hendrickson (1990).

(f) Reported in Welsh (1994a).

(g) Reported in Welsh (1994b).

(h) Reported in Welsh (1994C).

\section{VISCOSITY}

Viscosity of the laboratory-produced LLW vitrification simulants was measured using a Haake Rotovisco RV2O using a CS20 measuring sy.stem and a DA45 sensor according to procedure WHC-053-01. The viscosities at room temperature $\left(-23^{\circ} \mathrm{C}\right)$ are shown in Table 10 . 
IABLE 10. Viscosity of Laboratory-Prepared LLW Simulants

\begin{tabular}{lc} 
Simulant & Viscosity, CP \\
\hline DSSF, $6 \mathrm{M} \mathrm{Na}$ & $3.6 \pm 0.2$ \\
DSSF. $10 \mathrm{M} \mathrm{Na}$ & $11.1 \pm 0.2$ \\
RI, $6 \mathrm{M} \mathrm{Na}$ & $2.6 \pm 0.2$
\end{tabular}.

\section{MOISTURE CONTENT}

Samples of the laboratory-produced and pilot-scale simulants were dried at $120^{\circ} \mathrm{C}$ in a vacuum oven for several days to determine evaporable water or moisture content. Table 11 shows the results calculated after allowing the samples to cool under desiccation. Exposure of the dried. simulants to the atmosphere resulted in a rapid uptake of moisture because of the high salt content of the simulants. Moisture contents of samples from three waste tanks are also shown in Table 11.

IABLE 11. Moisture Content of Simulated or Actual Tank Waste Samples

$\begin{array}{lc}\begin{array}{c}\text { Simulant } \\ \text { or Tank Waste }\end{array} & \begin{array}{c}\text { Moisture } \\ \text { Content. Wt\% }\end{array} \\ \text { DSSF, } 6 \mathrm{M} \mathrm{Na} & 67 \\ \text { DSSF, } 10 \mathrm{M} \mathrm{Na} & 53 \\ \text { RI. } 6 \mathrm{M} \mathrm{Na} & 66 \\ \text { DSSF, } 10 \mathrm{M} \mathrm{Na} \text { (a) } & 57 \\ \text { 241-AP-102(b) } & 75 \\ \text { 241-AP-105(c) } & 60.3 \\ \text { 241-AP-106(d) } & 100.2 \\ & \\ \text { (a) From PNL pilot-scale test } \\ \text { (b) Reported in Welsh (1994a) } \\ \text { (c) Reported in Welsh (1994b) } \\ \text { (d) Reported in Welsh (1994c) }\end{array}$


PVTD-C95-02.03J

\section{CHEMICAL ANALYSES}

Chemical analyses were conducted on the $L L W$ vitrification simulants to compare the analyzed concentrations with the target values. For the 1 aboratory-produced samples, inductively coupled argon plasma emission spectrometry (ICP) was conducted with a Jarrell-Ash Model 975 ICP according to procedure PNL-ALO-211.2 Rev. 0 . The solutions were acidified using 2 vol\% nitric acid. Anion concentrations were measured using a Dionex Series $4000 i$ Ion chromatograph according to procedure PNL-ALO-212 Rev. 1. Carbon analyses was conducted using a Xertex-Dohrmann Model DC-80 carbon analyzer according to procedure PNL-ALO-382.1 Rev. 0 . The free hydroxide content was determined by titration. A summary of the analytical results are shown in Table 12 . The analyzed composition of all of the major species in the laboratory-produced simulant, except for hydroxide and carbonate, were within $10 \%$ of the target composition. The hydroxide content for the DSSF simulants averaged about $23 \%$ lower than the target value and the average carbonate concentrations were ranged from 54 to $78 \%$ higher than the target values. These discrepancies are not unexpected because atmospheric $\mathrm{CO}_{2}$ is readily absorbed by highly alkaline solutions consuming free hydroxide and producing additional carbonate ions.

Table 13 lists the chemical analyses results of the LLW vitrification simulants prepared by Optima Chemical. The analyses were conducted both at PNL and by Quanterra (See Appendices $B$ and $C$ ). Discussions regarding the applicability of the analyses to the needs of the program are found in the narratives of Appendices $B$ and $C$ and will not be repeated here. 
IABLE 12. Analyzed Chemical Composition of Laboratory-Produced Simulants, moles/L.

\begin{tabular}{|c|c|c|c|c|c|c|}
\hline \multirow[b]{2}{*}{ Component } & \multicolumn{2}{|c|}{$\begin{array}{l}\text { DSSF } \\
6 \mathrm{MNa}\end{array}$} & \multicolumn{2}{|c|}{$\begin{array}{c}\text { DSSF } \\
10 \mathrm{M} \mathrm{Na}\end{array}$} & \multicolumn{2}{|c|}{$\begin{array}{l}\text { Remaining } \\
\text { Inventory }\end{array}$} \\
\hline & Target & Analyzed & Target & Analyzed & Target & Analyzed \\
\hline Al & 0.61 & 0.61 & 1.02 & 0.95 & 0.16 & 0.16 \\
\hline $\mathrm{Ca}$ & 0.00063 & 0.00055 & 0.00105 & 0.00060 & 0.0004 & 0.00015 \\
\hline $\mathrm{Cr}$ & 0.0052 & 0.0052 & 0.00867 & 0.0083 & 0.0042 & 0.0041 \\
\hline $\mathrm{Fe}$ & 0.00046 & 0.00061 & 0.000767 & 0.00097 & 0.00024 & $<0.00018$ \\
\hline$k$ & 0.30 & 0.27 & 0.50 & 0.44 & 0.0058 & $<0.010$ \\
\hline $\mathrm{Mg}$ & 0.00062 & $<0.00058$ & 0.00103 & $<0.0016$ & 0.0000011 & $<0.00082$ \\
\hline$M n$ & 0.00025 & 0.00015 & 0.000417 & 0.00022 & 0.001 & 0.00062 \\
\hline Mo & 0.01 & 0.01 & 0.0167 & 0.015 & 0.01 & 0.01 \\
\hline $\mathrm{Na}$ & 6.0 & 5.7 & 10.0 & 9.07 & 6.0 & 5.6 \\
\hline$S r$ & 0.01 & 0.01 & 0.0167 & 0.016 & 0.01 & 0.01 \\
\hline $\mathrm{Cs}$ & 0.01 & $N A^{(a)}$ & 0.0167 & $N A^{(a)}$ & 0.01 & $N A^{(a)}$ \\
\hline $\mathrm{PO}_{4}$ & 0.026 & 0.027 & 0.0433 & 0.047 & 0.11 & 0.012 \\
\hline $\mathrm{IO}_{3}$ & 0.01 & $N A(a)$ & 0.0167 & $N A(a)$ & 0.01 & $N A(a)$ \\
\hline $\mathrm{CO}_{3}$ & 0.16 & 0.29 & 0.267 & 0.41 & 0.05 & 0.04 \\
\hline $\mathrm{Cl}$ & 0.096 & 0.094 & 0.127 & 0.17 & 0.0092 & 0.0062 \\
\hline $\mathbf{F}$ & 0.15 & 0.12 & 0.25 & 0.32 & 0.13 & 0.12 \\
\hline $\mathrm{SO}_{4}$ & 0.026 & 0.027 & 0.0433 & 0.042 & 0.038 & 0.037 \\
\hline $\mathrm{NO}_{3}$ & 1.9 & 1.8 & 3.11 & 2.90 & 3.5 & 3.5 \\
\hline $\mathrm{NO}_{2}$ & 1.0 & 1.0 & 1.67 & 1.65 & 0.26 & 0.24 \\
\hline $\mathrm{OH}$ & 2.3 & 1.8 & 3.8 & 2.8 & 1.5 & 1.5 \\
\hline TOC & 0.81 & 0.78 & 1.35 & 1.15 & 0.11 & 0.11 \\
\hline
\end{tabular}

(a) Not analyzed 
IABLE 13. Chemical Analysis of LLW Simulant Prepared By. Optima Chemicals

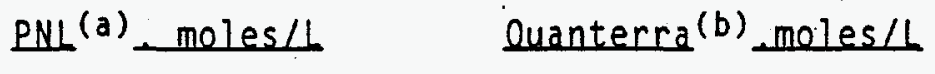

Component

A1

$\mathrm{Ca}$

$\mathrm{Cr}$

$\mathrm{Fe}$

K

$\mathrm{Mg}$

$\mathrm{Mn}$

Mo

$\mathrm{Na}$

$\mathrm{Sr}$

Cs

$\mathrm{PO}_{4}$

$\mathrm{IO}_{3}$

$\mathrm{CO}_{3}$

Cl

$F$

$\mathrm{SO}_{4}$

$\mathrm{NO}_{3}$

$\mathrm{NO}_{2}$

$\mathrm{OH}$

TOC

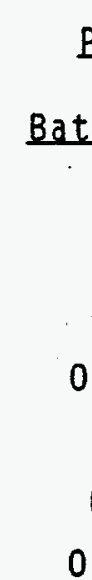

$$
\begin{gathered}
0 \\
0 \\
0 . \\
0 \\
0 .
\end{gathered}
$$

0.96

Batch 3

Batch 182

1.15

0.0025

0.009

0.0062

0.00072

0.51

0.0025

0.00047

0.0177

9.52

0.016

0.0154

0.036

0.0197

0.29

0.127

0.037

3.03

1.65

3.04

1.45

0.01

0.0013

0.61

0.0021

0.00064

0.02

10.6

0.018

0.017

0.039

0.025

0.38

0.14

0.25

0.16

0.04

0.045

0.04

3.05

1.9

2.95

1.63

3.75

1.65

1.46 Batch 3

1.31

0.0104

0.00115

0.58

0.022

10.46

0.015

0.027

0.036

0.017

0.3

0.18

Target

values

1.02

0.001

0.0087

0.00077

0.5

0.001

0.00042

0.017

0.017

0.017

0.043

0.017

0.27

0.13

0.25

(a) Analyses conducted by PNL (See Appendices B and C)

(b) Analyses conducted by Quanterra (See Appendices $B$ and $C$ ) 


\section{DATA NEEDS AND RECOMMENDATIONS}

Tank waste simulants have been used for many years on the GDP for developing grout formulations and for testing process conditions. The DST simulants were based on tank waste analyses and were generally more dilute than the actual tank wastes because of the need for blending with dilute tanks to reduce the concentration of heat-producing radionuclides. The only properties that were routinely measured for both the tank wastes and the simulants were chemical composition and density. Moisture content was reported for some of the DST waste samples.

The simulants proposed for the first phase of LLW melter vendor tests are also based on the analyses of DSTs: however, these simulants reflect compositional changes that could occur as the wastes undergo ion exchange and evaporation. The main emphasis of the current LLW vitrification simulant development was to develop and recommend a procedure for preparing large quantities of simulants for use in melter vendor tests. Although a procedure to prepare the simulant for melter vendor tests was proposed (Lokken and Martin 1994 and Shade 1994), the actual procedures used by the vendor (Optima Chemical) deviated from the recommended procedure because of reasons discussed above. Although the deviations in the procedures and potential implications were discussed with knowledgeable personnel prior to implementation. no laboratory data were available to substantiate the anticipated results. In addition, the only acceptance criteria for the simulants were based on composition determined from chemical analyses.

The following describes recommendations for future simulant development and characterization:

1) Prepare the simulant(s) at an ionic concentration expected at the exit of the ion exchange process, i.e., relatively dilute.

2) Concentrate the simulant(s) by evaporation and determine chemical composition and moisture content; measure density, undissolved solids. and viscosity as a function of temperature. 
3) Substitute other compounds in the simulant preparation procedure: prepare and characterize as in 1 and 2 above.

4) Conduct waste simulant compositional variability studies: prepare and characterize as in 1 and 2 above.

5) Determine the effects of "spikes", i.e., species added at concentrations greater than the nominal or average levels, on the properties of simulants; prepare and characterize as in 1 and 2 above.

6) Perform confirmation tests with actual wastes when they become available. 


\section{REFERENCES}

Bagasen, L. M. 1993. 106-AN Grout Pilot-Scale Test HGTP-93-0501-02.

PNL-8618. Pacific Northwest Laboratory, Richland, Washington.

Claghorn, R. D. 1987. Compositional Limits for Grout Feed: Double-Shell Slurry Feed and Retrieved Double-Shell Slurry Formulation Experiments. RHORE-EV-96. Rockwell Hanford Operations, Richland, Washington.

Fow, C. L., D. H. Mitchel1, R. L. Treat, and C. R. Hymas. 1987 Pilot-Scale Grout Production Test with a Simulated Low-Level Waste. PNL-6148. Pacific Northwest Laboratory. Richland. Washington.

Hammitt, A. P. and T. L. Welsh. 1993. Grout Formulation Verification: Tank 241-AN-106 Simulant Waste-Variability Test Results. WHC-SD-WM-TRP-068, Rev:

0 . Westinghouse Hanford Company, Richland, Washington.

Hendrickson, D. W. 1990. Methods and Data for Use in Determining Source Terms for the Grout Disposal Program. WHC-SD-WM-TI-355, Rev: 1 . Westinghouse Hanford Company, Richland, Washington.

Hendrickson. D. W. 1991. Grout Treatment Facility Waste Feed Acceptance Criteria. WHC-SD-WM-RD-019, Rev. 1. Westinghouse Hanford Company, Richland. Washington.

Hendrickson, D. W. 1991. Tank 241-AW-101 Characterization Results. WHC-SDWM-TRP-055, Rev. 0. Westinghouse Hanford Company, Richland, Washington.

Hendrickson. D. W. and J. M. Conner. 1994. Grout Treatment Facility Waste Feed Projections. WHC-SD-WM-TI-528, Rev. 1, Westinghouse Hanford Company, Richland, Washington.

Hendrickson. D. W. and T. L. Welsh. 1992. Hanford Grout Disposal Program Campaign 102 Sampling and Characterization Plan. WHC-SD-WM-TP-136. Westinghouse Hanford Company, Richland. Washington.

Lokken. R. 0. 1992a. Formulation Verification Study Results for Tank 106-AN Waste. PNL-7966, Pacific Northwest Laboratory, Richland, Washington.

Lokken, R. 0. 1992b. Durability of Double-Shell Tank Waste Grouts. PNL-7835, Pacific Northwest Laboratory, Richland, Washington.

Lokken. R. 0. 1992c. Heat of Hydration of Double-Shell Slurry Feed Grouts.

PNL-7860. Pacific Northwest Laboratory, Richland, Washington.

Lokken, R. O. and P. F. C. Martin. 1994. Makeup Precedures and

Characterization Data for Simulated Low-Level Wastes. TDD-94-151, C94-21.04E, Pacific Northwest Laboratory. Richland, Washington. 
Lokken. R. 0., P. F. C. Martin. L. C. Morrison. S. E. Palmer, and C. M. Anderson. 1993. Formulation Verification Study Results for 241-AN-106 Waste Grout. PNL-8626. Pacific Northwest Laboratory, Richland. Washington.

Lokken, R. 0.. P. F. C. Martin, W. M. Bowen, H. Harty and R. L. Treat. 1987. Variability in Properties of Grouted Phosphate/Sulfate $N$-Reactor Waste. PNL6030. Pacific Northwest Laboratory, Richland, Washington.

Lokken. R. 0.. P. F. C. Martin. 1992. Durability of Double-Shell Slurry Feed Grouts: FY-90 Results. PNL-7838. Pacific Northwest Laboratory. Richland, Washington.

Serne, R. J., R. O. Lokken, and L. J. Criscenti. 1992. "Characterization of Grouted Low-Level Waste to Support Performance Assessment," in Waste Management. Vol. 12. Pergamon Press Ltd., pp. 271-287.

Serne, R. J., W. J. Martin, R. 0. Lokken, V. L. LeGore, C. W. Lindenmeier, P. F. C. Martin. 1989. Leach and EP Toxicity Tests on Grouted Waste From Tank 106-AN. PNL-6960. Pacific Northwest Laboratory, Richland, Washington.

Serne, R. J., W. J. Martin, V. L. LeGore, C. W. Lindenmeier, S. B. McLaurine, R. O. Lokken, P. F. C. Martin. 1989. Leach Tests on Grouts Made with Actuai and Trace Metal-Spiked Synthetic Phosphate/Sulfate Waste. PNL-7121. Pacific Northwest Laboratory, Richland, Washington.

Shade, J. W.. R. 0. Lokken and D. M. Strachan. 1986. Pore Fluid Chemistry of Grouts with Organic Complexant Waste. PNL-SA-13551. Presented at the American Ceramic Society. Inc. 88th Annual Meeting. Chicago, Illinois, April 27-May 1. 1986.

Shade. J. W. 1994. Waste Simulant Development for Evaluation of LWW Melter System Technology. WHC-SD-WM-TI-624. Westinghouse Hanford Company, Richiand, Washington.

Welsh. T. L. 1994a. Tank 241-AP-102 Characterization and Grout Product Test Results. WHC-SD-WM-TRP-168, Rev. 1. Westinghouse Hanford Company, Richland, Washington.

Welsh. T. L. 1994b. Iank 241-AP-105 Characterization Results. WHC-SD-WMTRP-169, Rev. 0, Westinghouse Hanford Company, Richland. Washington.

Welsh, T. L. 1994C. Iank 241-AP-106 Characterization Results. WHC-SD-WMTRP-170, Rev. 0. Westinghouse Hanford Company, Richland. Washington.

Whyatt. G. A. 1994. Pilot-Scale Production of Grout with simulated Double-Shell slurry Feed. PNL-9746. Pacific Northwest Laboratory. Richland, Washington.

Wilson, C. N. 1994. Evaluation of Melter-System Technologies for Vitrification of Hiah-Sodium Content Low-Level Radioactive Liquid Wastes, WHC-SD-WM-RD-044, Rev. 0 , Westinghouse Hanford Company, Richland. Washington. 


\section{APPENDIX A}

Shafer. Phyllis. "LLW Simulant". DSI to Ryan Lokken, 9/7/94. 
Date: $\quad 09 / 07 / 94$

To: $\quad$ Ryan Lokken

From: Phyllis Shafer

Subject: LLW Simulant

I have gone over all of my analysis results for the simulant, and discovered that the only complete test results I have are for the feed samples with glass formers added. I don't have a complete analysis for this simulant, therefore I would strongly recommend that you have it analyzed before working with it. Keep in mind that when we made up the feed, we initially only added $1 / 2$ of the required $\mathrm{NaOH}$. Later, we discovered the mistake and fixed it when we added the glass formers. This sample is still short on $\mathrm{NaOH}$. Without a more accurate analysis, I can't tell you how much $\mathrm{NaOH}$ needs to be added because I don't know how dilute/concentrated this sample is. I can only tell you how much of each chemical was added to make up this sample, but there was an unknown amount of additional water added.

Here is the chemical list that made up this feed:

\begin{tabular}{|c|c|}
\hline Compound & total $\mathrm{lb}$ \\
\hline $\begin{array}{l}\mathrm{AI}(\mathrm{NO} 3) 3 * 9 \mathrm{H} 2 \mathrm{O} \\
(60 \text { wt\% solution) }\end{array}$ & 1330 \\
\hline $\mathrm{Ca}(\mathrm{NO} 3) 2 * 4 \mathrm{H} 2 \mathrm{O}$ & 0.50 \\
\hline $\mathrm{Cr}(\mathrm{NO} 3) 3 * 9 \mathrm{H} 2 \mathrm{O}$ & 7.20 \\
\hline $\mathrm{Fe}(\mathrm{NO} 3) 3 * 9 \mathrm{H} 2 \mathrm{O}$ & 0.64 \\
\hline $\mathrm{KOH}$ & 58.08 \\
\hline $\mathrm{Mg}(\mathrm{NO} 3) 2 * 6 \mathrm{H} 2 \mathrm{O}$ & 0.55 \\
\hline $\mathrm{Mn}(\mathrm{NO} 3) 2$ & 0.15 \\
\hline $\mathrm{Na2MOO} 4 * 2 \mathrm{H} 2 \mathrm{O}$ & 8.36 \\
\hline $\mathrm{SrCl}$ & 5.48 \\
\hline CsNO3 & 6.74 \\
\hline $\mathrm{NaH} 2 \mathrm{PO}_{4}^{*} \mathrm{H} 2 \mathrm{O}$ & 12.36 \\
\hline $\mathrm{NaIO3}$ & 6.84 \\
\hline $\mathrm{Na}_{2} \mathrm{CO} 3$ & 58.5 \\
\hline $\mathrm{NaCl}$ & 15.34 \\
\hline $\mathrm{NaF}$ & 21.76 \\
\hline $\mathrm{Na2SO4}$ & 12.76 \\
\hline NaNO2 & 238.1 \\
\hline $\mathrm{NaOH}$ & 276 \\
\hline Na4EDTA & 116.34 \\
\hline
\end{tabular}

Note: the $\mathrm{NaOH}$ quantity should have been $552 \mathrm{lb}$. 
PVTD-C95-02.03J

\section{APPENDIX B}

Kelly, S. E. "Analysis of Optima Chemicals" 10 Na Molar DSSF Simulant". DSI to W. B. Haskins, $9 / 8 / 94$. 


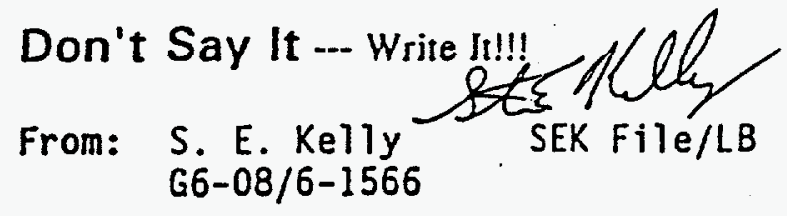

September 8, 1994

To: H. B. Haskins G1-61

$\begin{array}{ll}\text { cc: K. C. Burgard } & \text { R4-01 } \\ \text { H. C. Eaton } & H 5-27 \\ \text { D. H. Hendrickson } & \text { L5-31 } \\ \text { B. A. Higley } & H 5-27 \\ \text { R. O. Lokken } & P 8-37 \\ \text { K. N. Pool } & P 8-44 \\ \text { R. G. Seymour } & H 5-27 \\ \text { E. J. Slaathaug } & H 5-49 \\ \text { J. S. Shade } & \\ \text { G. E. Stegen } & H 5-27 \\ \text { J. M. Perez } & \text { P7-41 } \\ \text { C. N. Hilson } & \text { CUIU H5-27 } \\ \text { E. T. Weber } & H 5-27\end{array}$

ANALYSIS OF OPTIMA CHEMICALS' $10 \mathrm{Na}$ MOLAR DSSF SIMULANT

Attached are a summary of the chemical additions and analyses of samples from the 7000 gallons of 10 molar sodium (Na) DSSF simulant manufactured at Optima Chemicals. The analysis from PNL and Quanterra were reported in draft reports. Values: are not expected to change in the final reports.

Quanterra reported low values for nitrate, nitrite, carbonate, and fluoride, and a high value for alkalinity (hydroxide). The analyses of these analities are suspect and were not used in the acceptance of the simulant. Quanterra also reported a sodium concentration of $15 \%$ below the simulant target value. This is hard to explain with the alkalinity number so high.

PNL reported low values for sodium $(7 \%$ or 0.7 moles/liter below target concentration), alkalinity (27\% or 0.8 moles/ $/$ iter below target concentration), and fluoride. Karl Pool, from PNL, stated that sodium fluoride would precipitate out in a 10 molar sodium solution and that this has been observed in the past. Therefore PNL chose not to report a final fluoride value in the DSSF solution (this also explains the low value reported by Quanterra). Optima Chemicals chemical addition records show the correct amount of fluoride added. The sodium and hydroxide values indicate that the simulant could be approximately 0.7 moles per liter short in sodium hydroxide $(\mathrm{NaOH})$. Optima Chemicals chemical addition records and WHC personnel overseeing the addition of simulant compounds verify the correct addition of sodium hydroxide. All other simulant components as analyzed by PNL were reported within limits acceptable to the Low Level Waste Program.

Based on discussions with WHC personnel who witnessed chemical additions, Karl Pool of PNL, and Optima Chemicals' chemical addition records. TWRS Vitrification Development Sections recommends the acceptance of the $10 \mathrm{M}$ Na as manufactured on August 16, 1994.

\section{To Make Life Last - Put Safety First.}


Analy sis of Oplima Chemicals' 10. Molar DSSF Simulant

-. PNL data lrom Karl Pool "Orafl Roporl' daled Seplomber 7, 1894.

- Quanlerra dala from Wado H. Prlco facsimlle daled Seplember 2, 1994

- $222-5$ informallon was relayed on sample stalus report for A 6243. MISC- 1 (Goorgla)

daled August 30, 1994. Tho chain of custody was broken on thls sample, however there

There was no menllon of Indlcallons of samplo tampering.
Development dala is liom WHC-SO-WM-TI-624 Rey O.

\begin{tabular}{|c|c|c|c|c|c|c|c|c|c|c|}
\hline \multirow[b]{2}{*}{ Componenl } & \multirow[b]{2}{*}{ Alomlc WL } & \multirow[b]{2}{*}{ Compound } & \multirow[b]{2}{*}{$\begin{array}{l}\text { Formula } \\
\text { Wolght }\end{array}$} & \multicolumn{4}{|c|}{$10 M 010 \mathrm{NaOSSF}$} & \multicolumn{3}{|l|}{ simulan! } \\
\hline & & & & $\begin{array}{l}\text { \% Molognt } \\
2 \% \text { noquifod }\end{array}$ & $\begin{array}{c}\text { Datch t } \\
\text { Ibs/3500 gal } \\
\end{array}$ & $\begin{array}{c}\text { Datch } 2 \\
\text { Use/3500 oal } \\
\end{array}$ & 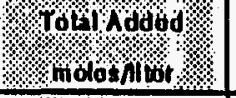 & $\begin{array}{c}\text { Targot } \\
\text { molos mllor }\end{array}$ & $\begin{array}{c}\text { PNL } \\
\text { molos nitor }\end{array}$ & $\begin{array}{l}\text { Quanioisa } \\
\text { mnlos/utor }\end{array}$ \\
\hline Alt+t+ & 20.981 & $\mathrm{Al}(\mathrm{NO}) 3 \cdot 9 \mathrm{H} 2 \mathrm{O}$ & 375.14 & $1+\bigcirc \quad 1.02$ & 11105 & 11103.4 & $1 \% 1 \%$ 10:0 & 1.02 & 0.00 & 0.05 \\
\hline $\mathrm{Ca}++$ & 40.08 & $\mathrm{Ca}(\mathrm{NO} 3) 2 * 4 \mathrm{H} 2 \mathrm{O}$ & 236.16 & ४) \& 0.001 & 6.93 & 6.83 & 30,0010 & 0.001 & 0.0025 & 0.0028 \\
\hline Crt+ & 51.890 & $\mathrm{Cl}(\mathrm{NO}) 3 \cdot \mathrm{BH} 2 \mathrm{O}$ & 100.17 & उस $\quad 0.0007$ & 10.192 & 13.2502 & 1., $00000 t$ & 0.0007 & 0.0062 & 0.0074 \\
\hline $\mathrm{Fat+t}$ & 55.047 & $\mathrm{Fe}(\mathrm{NO} 3)^{3} \cdot \mathrm{gH}_{2} \mathrm{O}$ & 104.01 & 18 0.00071 & 1.2705 & 1.26 & $0.0007 \%$ & 0.00077 & 0.00072 & 0.00006 \\
\hline$k+$ & 39.102 & KOH & 56.1 & $30 \quad 0.5$ & 819.4775 & 018.4775 & $18 \%, 3 \%$ 05 & 0.5 & 0.51 & 0.1 \\
\hline$M_{0++}$ & 24.312 & $\mathrm{Mg}(\mathrm{NO} 3) 2^{\circ} 6 \mathrm{H} 2 \mathrm{O}$ & 256.41 & $10 \div \quad 0.001$ & 7.524 & 7.450 & 1300001 & 0.001 & 0.0025 & 0.0031 \\
\hline$M n++$ & 54.038 & Mn(NO3)2 & 176.94 & 1ै. $\quad 0.00012$ & 2.2 & 2.15 & 8000042 & 0.00042 & 0.00047 & 0.00044 \\
\hline Mo+o & 95.94 & $\mathrm{Na} 2 \mathrm{MoO}{ }^{\circ} \mathrm{H} 2 \mathrm{O}$ & 241.05 & 1) $\quad 0.017$ & 120.100 & 120.186 & \$, $0.01 \mathrm{i}$ & 0.017 & 0.0177 & 0.0105 \\
\hline $\mathrm{Na}+$ & 22.90 & & & 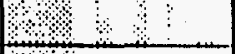 & & & $18.1, \%, 10,0$ & 10.0 & 9.20 & 0.5 \\
\hline sitt & 87.62 & $\mathrm{SrCl} 2$ & 150.52 & 3\% $\quad 0.017$ & 78.771 & 70.771 & $1 \% \%, \quad 0.017$ & 0.017 & 0.0160 & 0.0130 \\
\hline Cst & 132.8 & CsNO3 & 194.91 & $1 \% \% ? 0,011$ & 96.806 & 96.006 & 20017 & 0.017 & 0.0154 & 0.0106 \\
\hline POA--- & 04.98 & $\mathrm{NaH} 2 \mathrm{PO}_{4}{ }^{\circ} \mathrm{H} 2 \mathrm{O}$ & 130 & $1 \% \% 8 \quad 0.043$ & 150.7177 & 150.7177 & $0,0,037$ & 0.043 & 0.036 & 0.038 \\
\hline $103-\cdots$ & 174.9 & $\mathrm{NalO3}$ & 197.89 & $1 \%$ \& o.017 & 08.3060 & 98.3066 & 1.0 .018 & 0.017 & 0.0187 & - \\
\hline $\cos --$ & 60 & $\mathrm{Na} 2 \mathrm{CO} 3$ & 106 & $12 \%, 3,0.27$ & 836.163 & B36.163 & $1 \%$ Q 0.21 & 0.27 & 0.29 & 0.05 \\
\hline $\mathrm{Cl}-$ & 35.453 & $\mathrm{NaCl}$ & 58.45 & $1 \% ? \quad 0.13$ & 215.2105 & 215.2185 & 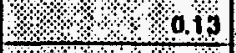 & 0.10 & 0.127 & 0.16 \\
\hline$F-$ & 18 & NaF & 42 & $1 \% \% \quad 0.25$ & 306.770 & 306.778 & $1 \%, 3<0.25$ & 0.25 & (note 2) & 0.04 \\
\hline SO4-- & 90.064 & $\mathrm{Na2sO4}$ & 112.06 & Qै $\quad 0.013$ & 178.503 & 178.503 & & 0.043 & 0.037 & 0.040 \\
\hline NO3 - & 62 & & & 12 : & & & ४ै1\% \% 3.1 & 3.1 & 3.03 & 0.67 \\
\hline NO2 - & 11 & $\mathrm{NaNO} 2$ & 69 & $12, \quad 3$ & 3427.0360 & 3427.0360 & ४ै, 11 & 1.7 & 1.65 & 0.50 \\
\hline $\mathrm{OH}-$ & 17 & $\mathrm{NaOH}$ & 40 & $12 \%: 6.7$ & 7031.3536 & 7030.004 & 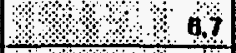 & 3.0 & 3.04 & 10.8 \\
\hline $10 c$ & 12 & Na4EDTA (C10) & \$16.2 & $12 \% \quad 0.14$ & 1555.410 & 1555.1277 & 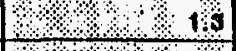 & 1.4 & 1.45 & 1.40 \\
\hline pH & & & & २ै, & & & $1,1,43$ & & & 13.5 \\
\hline
\end{tabular}

\begin{tabular}{|c|c|c|c|}
\hline \multirow[b]{2}{*}{ Analysis } & \multirow{2}{*}{$\begin{array}{c}\text { Dovolopmont } \\
\text { Dala }\end{array}$} & \multicolumn{2}{|c|}{ Looralory } \\
\hline & & PNL & $222-5$ \\
\hline Denslly & 1.12 & 1.453 & 1.4274 \\
\hline x Selllod Sollds & $<5$ & & 2.7 \\
\hline x Centilluged Solld (volume) & & & 1.5 \\
\hline
\end{tabular}


PVTD-C95-02.03J

\section{APPENDIX C}

Kelly, S. E. "Analysis of Optima Chemicals' 10 Na Molar DSSF Simulant October 13th Batch". DSI to W. B. Haskins, 11/10/94. 
Don't Say It - Write It!!!

November 10, 1994

From: S. E. Kelly

G6-08/6-1566

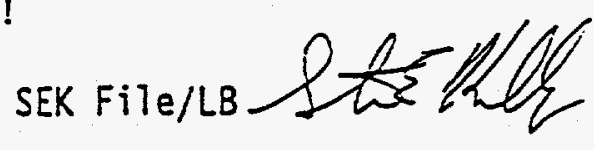

To: H. B. Haskins Gl-61

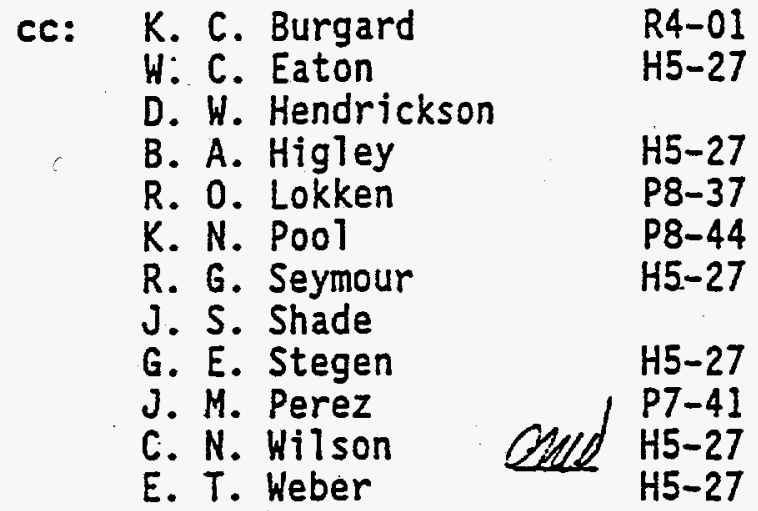

ANALYSIS OF OPTIMA CHEMICALS' 10 Na MOLAR DSSF SIMULANT OCTOBER 13th BATCH Attached are a summary of the chemical additions and analyses of samples from the 4100 gallons (batch 3 ) of 10 molar sodium (Na) DSSF simulant manufactured at Optima Chemicals.

Quanterra reported low values for nitrate (12\%) and total organic carbon (35\%), and a high vaiues for aluminum (28\%), potassium (16\%), and nitrite (41\%).

PNL reported high values for aluminum (13\%), potassium (22\%), sodium (6\%), carbonate (42\%), and total organic carbon (22\%). As with the analysis of the first batch of simulant, PNL did not report a value for fluoride due to its solubility in the simulant and the laboratories in-ability to accurately recover it.

Optima Chemicals' chemical addition records show all chemicals added in correct amounts. Additions were witnessed by a WHC representative, R. G. Seymour.

Review of laboratory data shows that this simulant batch appears to be more concentrated than the simulant manufactured on August 16, 1994. The density analyses also support this conclusion. The most important components of the simulant, which are out of specification, are aluminum and sodium. Aluminum is also a component of each melter vendors glass formers and the amount of deviation in the simulant should not adversely affect melter operations (it is possible that the aluminum nitrate solution used for production was more concentrated than expected). The sodium values for the two analyses agree well and an average value indicates that the simulant is just above the 10.5 mole/liter sodium specification. The sodium concentration should not adversely affect melter testing.

TWRS Vitrification Development Sections recommends the acceptance of the $10 \mathrm{M} \mathrm{Na}$ as manufactured on October 13,1994 .

To Make Life Last - Put Safety First. 
- PN data Is tom a lacslmlle of the summary and discusslon secilon of the llnalieport.

- Qua nlerra da e trom Wade H. Price repal dated November I. 1894

- Development de ts trom WHIC-8D-WM-TI-624 Aov. 0 .

- Opuma addillons are trom Regan Sey mour's tlp report da led October 14, 1994.

- Fesulta trom the August 16 th batch ( \& 2) of 7000 gallons of slmulant aro provided lor comparlson.

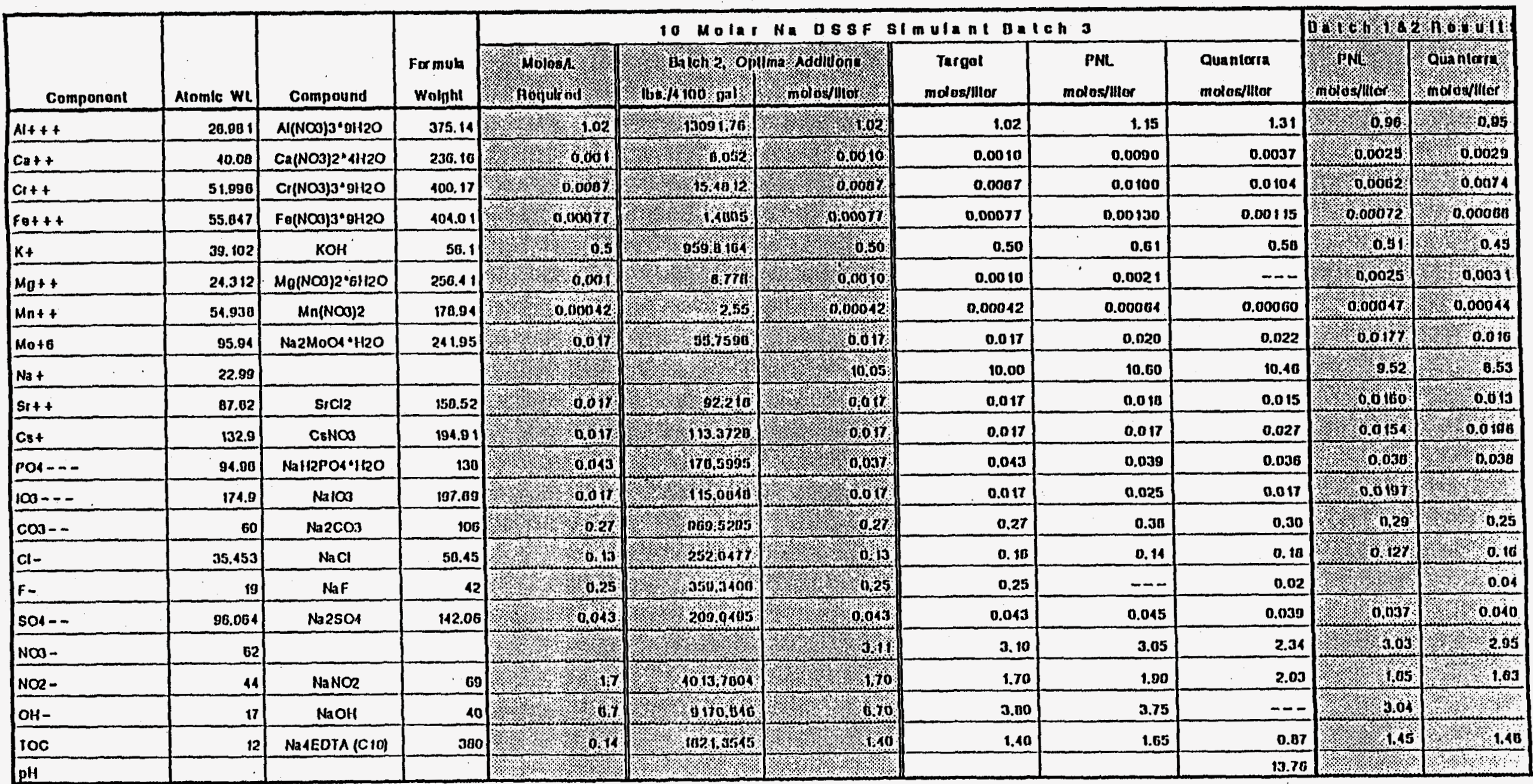

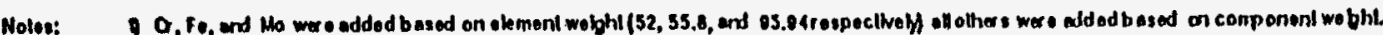

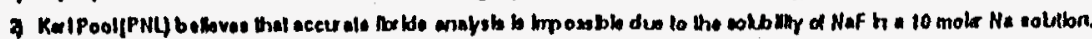

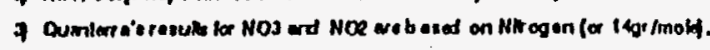

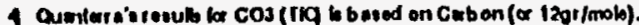

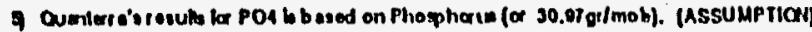

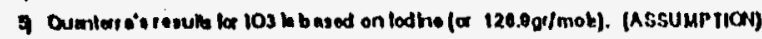

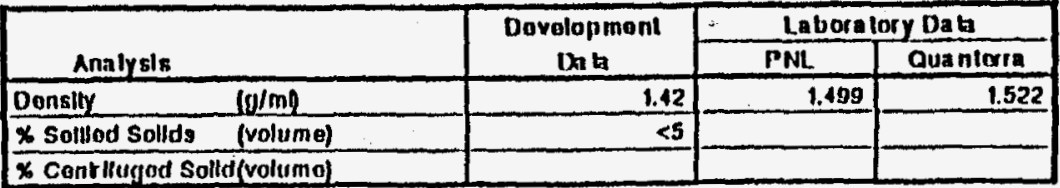

